\title{
Stability and spatio-temporal structure in fish assemblages of two floodplain lagoons of the lower Orinoco River
}

\author{
Nirson González ${ }^{1,2}$, Carlos Lasso ${ }^{3,4}$ and Judith Rosales ${ }^{5}$
}

Fish assemblage structure and variability were analyzed in two floodplain lagoons (Las Arhuacas and Los Cardonales) along the lower Orinoco over a hydrological cycle. Every three months during continuous three-day sampling, experimental gill nets ( 5 to $12.5 \mathrm{~cm}$ of mesh opening) and $1 \mathrm{~mm}$-mesh seine nets were utilized according to the types of habitats presents. A total of 133 fish species were found in Las Arhuacas and 95 species in Cardonales. Fifty five and 17 species were exclusive to Las Arhuacas and Los Cardonales respectively, and 77 were common to both lagoons. In Las Arhuacas, the most speciesrich orders were Characiformes, Siluriformes, Perciformes and Gymnotiformes and in Los Cardonales, the most species-rich orders were Characiformes, Siluriformes, Clupeiformes and Perciformes. The richness, abundance and biomass were significantly higher $(\mathrm{p}<0.001)$ in Arhuacas than in Cardonales. In general, the fishes assemblage was highly variable during the high water phase and moderately stable during low water phase in both lagoons, with more stability or less variability in Cardonales than Arhuacas. Also, there were significant differences in the fish assemblages between the two lagoons, mainly during low waters (ANOSIM; $\mathrm{p}<0.001$ ). The species that contributed most to the mean dissimilarity between the lagoons were Hypostomus argus, Aphanotorulus ammophilus, Potamorhina altamazonica, Prochilodus mariae, Loricaria gr. cataphracta, Oxydoras sifontesi, Hydrolycus armatus, Hyphopthalmus edentatus and Pterodoras rivasi. The last four species were more commonly collected in Los Cardonales. Also, the species of small size (mainly $\mathrm{SL}<5 \mathrm{~cm}$ ) such as Rhinosardinia amazonica, Moenkhausia sp. 1 "lepidura", Moenkhausia sp. 2, Aphyocharax alburnus, Characidium sp. 1, Moenkhausia sp. 3, Exodon paradoxus and Roeboides dientonito contributed to the mean dissimilarity among the beach and aquatic vegetation habitats. The patterns of the species assemblage organization were related to the dynamics of the floods. Non-random (i.e., deterministic) associations between species caused by the selection of habitats and/or to biological interactions, apparently were more common during low waters when there is an increased density of fish and so the biotic interactions are intensified. Stochastic associations, on the other hand, seemed to be more common during high water when species are more dispersed.

Foram analisadas a estrutura e a variabilidade da comunidade de peixes ao longo de um ciclo hidrológico em dois lagos (Arhuacas e Cardonales) da planície de inundação do baixo rio Orinoco. Amostragens trimestrais foram realizadas por meio de coletas contínuas durante três dias, utilizando-se redes de espera experimentais ( 5 a $12,5 \mathrm{~cm}$ de malha) e redes de arrasto (1 mm de malha), de acordo com os tipos de habitats presentes. Foi encontrado um total de 133 espécies de peixes em Arhuacas e 95 espécies em Cardonales. Cinquenta e cinco espécies foram exclusivas do lago Arhuacas, 17 do lago Cardonales, e 77 foram comuns a ambos os lagos. Em Arhuacas, as ordens mais ricas em espécies foram Characiformes, Siluriformes, Perciformes e Gymnotiformes; em Cardonales, foram Characiformes, Siluriformes, Clupeiformes e Perciformes. A riqueza, abundância e biomassa foram significativamente mais altas $(\mathrm{p}<0.001)$ em Arhuacas que em Cardonales. A comunidade de peixes teve alta variação durante a fase de cheia e permanceu moderadamente estável durante fase de seca em ambos os lagos, com mais estabilidade ou menos variabilidade durante todas as fases do ciclo hidrológico em Cardonales que Arhuacas. Ademais, houve diferenças significativas nas comunidades ícticas entre os dois lagos, em especial durante o período da seca (ANOSIM; p < 0.001). As

\footnotetext{
${ }^{1}$ Estación de Investigaciones Hidrobiológicas de Guayana (EDIHG), Fundación La Salle de Ciencias Naturales, Apartado postal 51, San Félix, Estado Bolívar, Venezuela.

${ }^{2}$ Postgrado de Ciencias Ambientales, Mención Ecología Aplicada, Universidad Nacional Experimental de Guayana (UNEG), Estado Bolívar, Venezuela. nirson.gonzalez@fundacionlasalle.org.ve

${ }^{3}$ Sección de Ictiología, Museo de Historia Natural La Salle, Apartado postal 1930, Caracas 1010-A, Venezuela.

${ }^{4}$ Current address: Instituto de Investigación de Recursos Biológicos Alexander von Humboldt, Programa Biología de la Conservación y Uso de la Biodiversidad. Calle 28 A, número 15-09, Bogotá D.C., Colombia. classo@humboldt.org.co

${ }^{5}$ Centro de Investigaciones Ecológicas, Universidad Nacional Experimental de Guayana, UNEG, Venezuela. jrosales@uneg.edu.ve
} 
espécies que mais contribuíram para a dissimilaridade média entre os lagos foram Hypostomus argus, Aphanotorulus ammophilus, Potamorhina altamazonica, Prochilodus mariae, Loricaria gr. cataphracta, Oxydoras sifontesi, Hydrolycus armatus, Hyphopthalmus edentatus e Pterodoras rivasi. As últimas quatro espécies foram geralmente mais coletadas em Cardonales. As espécies pequenas (principalmente SL < $5 \mathrm{~cm}$ ), como Rhinosardinia amazonica, Moenkhausia sp. 1 "lepidura”, Moenkhausia sp. 2, Aphyocharax alburnus, Characidium sp. 1, Moenkhausia sp. 3, Exodon paradoxus e Roeboides dientonito, foram as que mais contribuiram para a dissimilaridade média entre os habitats de praia e de vegetação aquática. Os padrões de organização da comunidade foram relacionados à dinâmica das inundações. Assim, associações não aleatórias (i.e., determinísticas) entre espécies relacionadas à seleção de habitats e/ou interações biológicas foram, aparentemente, mais comuns durante o período de seca, quando há aumento da densidade de peixes e, por conseguinte, intensificação das interações bióticas. Por outro lado, associações aleatórias pareceram ser mais comuns durante o período de cheia, quando as espécies estão mais dispersas no ambiente.

Key words: Neotropical, Freshwater, Communities, Seasonality, Venezuela.

\section{Introduction}

Studies of tropical floodplain systems have generated increasing interest in the two last decades. Despite the fact that the importance of the fish in these ecosystems is well recognized, nevertheless there are still very few ecological studies in Venezuela that try to explain the processes responsible for the composition and abundance of fish communities in this system (Lasso, 1988a, 1988b, 1996; Jørgensen, 1994; Lasso et al., 1999; Jørgensen et al., 2000; Rodríguez \& Lewis, 1990, 1994, 1997). Moreover, these ecosystems contribute to the high productivity of the commercial fisheries in continental waters. This productivity is due to the great heterogeneity of habitats that occur within the floodplain. These habitats serve as hatcheries, shelter from predators, and feeding areas for many species of commercial importance as food or ornamental fish (MachadoAllison, 1994). Thus, in order to understand assemblage stability, it is fundamental that we understand those factors that may vary among ecosystems and that may influence the persistance of populations, these include varying interspecies interactions, geomorphologies and disturbance regimes. Therefore, by studying the stability of associations, one can learn about the behaviour of those systems influenced not only by wet and dry periods, but also by human impacts (Freeman et al., 1988; Medeiros \& Maltchik, 2001). However, more long-term studies of ecological characteristics are needed if one is to have a better understanding of the stability or persistence in fish assemblages (Freeman et al., 1988; Grossman et al., 1990). According to Meffe \& Minckley (1987), stability is the relative constancy of the abundance of species over a period of time in spite of disturbance. In Orinoco floodplain lagoons, several authors (Rodriguez \& Lewis, 1994; Winemiller, 1996) have argued that in spite of the variability in fish assemblage structure induced by the strong floods within years, there is stability across years, this means that, in the long term, assemblage properties recover and reflected in an adjustment or resilience. These adjustments are influenced by both deterministic and stochastic regulation.
In this paper, we examine species assemblage patterns at the microhabitat level during an whole hydrological cycle with the purpose of being able to observe more substantial variation in the species assemblages. Specifically, we evaluate the differences in fish assemblage structure between habitats within and across of two floodplain lagoons. Our objectives were to: 1 ) test for stability of fish assemblages during whole hydrological cycle; 2) evaluate the spatial-temporal variation in the fish assemblages across the habitats patches present in the lagoons and understand which random or deterministic associations persisted during the hydrological cycle.

\section{Material and Methods}

Study site. According to Vásquez \& Sánchez (1984), the lower Orinoco begins at the confluence of the Apure River with the Orinoco and extends until Barrancas in Delta Amacuro. However, Colonnello (1990) indicated that the Lower Orinoco starts at Atures Rapids, near Puerto Ayacucho. It went on to state that an extensive floodplain, with floodplain lagoons, begins at Caicara. The Orinoco basin is doubtless Venezuela's dominant hydrographic unit given its extent and the magnitude of its flow ca. $1.4 \times 10^{12} \mathrm{~m}^{3} / \mathrm{yr}$ (Zinck, 1977). The river drains a basin of $1.1 \times 10^{6} \mathrm{~km}^{2}$ shared by Venezuela (70\%) and Colombia (30\%). Hamilton \& Lewis (1990) report that the Lower Orinoco forms a floodplain of about $7000 \mathrm{~km}^{2}$ containing 2294 permanent floodplain lagoons. The Orinoco is about $2060 \mathrm{~km}$ long and has an annual average flow of about $36000 \mathrm{~m}^{3} / \mathrm{s}$ (Meade et al., 1983) (Fig. 1).

On the Orinoco's right bank, where the study lagoons are located (Fig. 1), the tributaries main that drain the Guayana Shield are the rivers Caroní and Caura which are characterized by their low conductivity and dark coloration due to high levels of dissolved organic carbon (Lewis et al., 1986). On its left bank, the Orinoco collects water from innumerable small rivers that drain the Venezuelan and Colombian Andes and the alluvial plains of the "Llanos". Largest amongst these tributaries are the Meta, Cinaruco, Capanaparo, Arauca and Apure. In the Orinoco basin, the precipitation tends to 


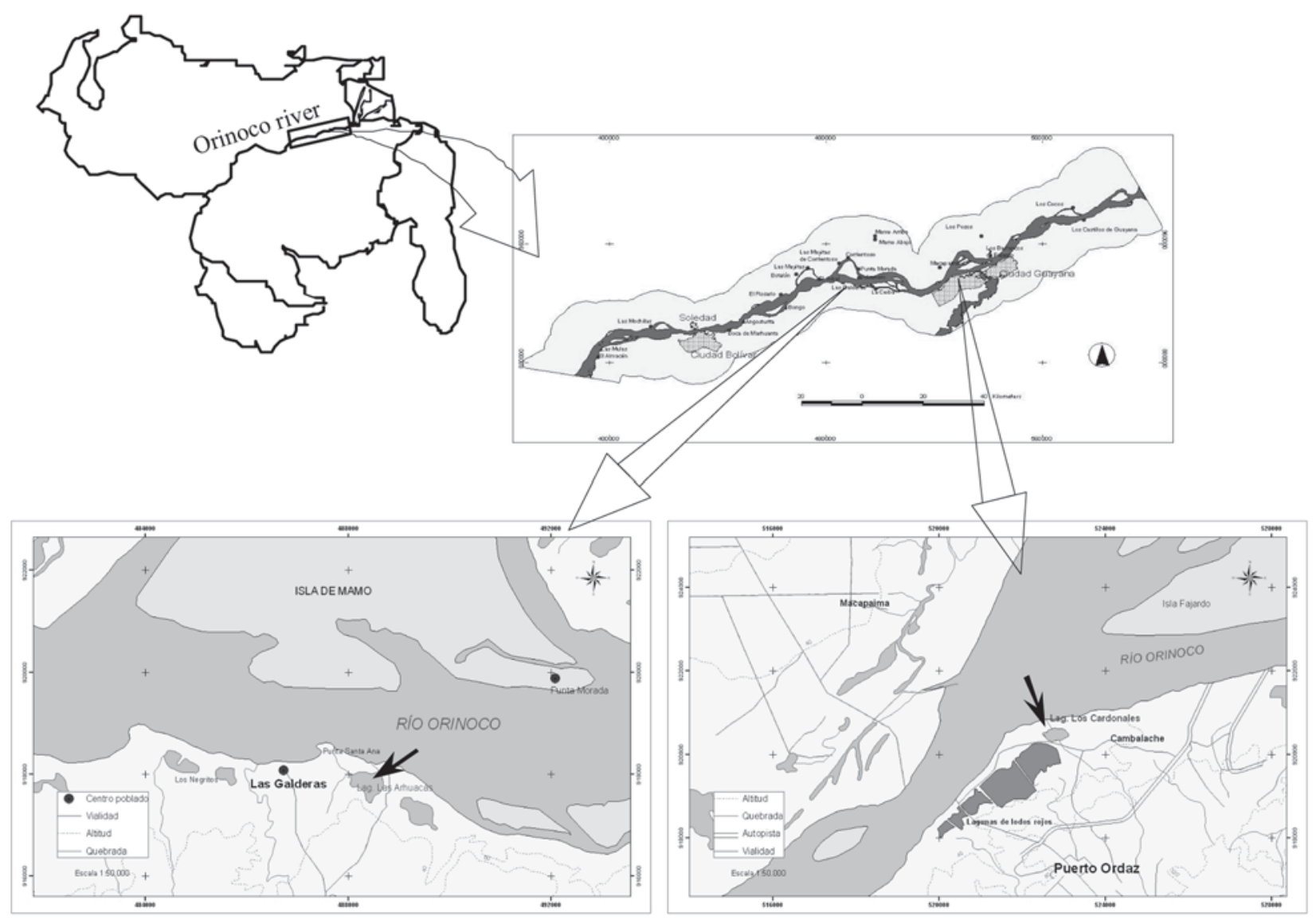

Fig. 1. Locations of the two studied lagoons in the right bank of the lower Orinoco river, between the cities of Puerto Ordaz and Ciudad Bolívar, Bolívar State, Venezuela. The arrows in black indicate the lagoons.

increase towards the south. In some northern areas, including in our study area, rainfall may reach only $1000 \mathrm{~mm} / \mathrm{year}$, whereas in southern portions of the basin, it can reach 6000 mm/year (Ewel et al., 1976). According to Sánchez \& Vásquez (1984), in our study area the difference between average high and low water levels can be 10 to $12 \mathrm{~m}$, with the period of high water extending from June to November.

Our study sites were two floodplain lagoons along the Orinoco's right bank. Los Cardonales lagoon located in an urban-industrial zone to the northwest of Puerto Ordaz (08 $19{ }^{\prime} 38^{\prime \prime} \mathrm{N} 62^{\circ} 47^{\prime} 36^{\prime \prime} \mathrm{W}$ ) with a maximum depth of $4.6 \mathrm{~m}$ and a surface area of 15 and 12.7 ha. at high and low water, respectively. The other lagoon is Las Arhuacas, located in the rural sector Las Galderas (08 $\left.18^{\prime} 14^{\prime \prime} \mathrm{N} 63^{\circ} 06^{\prime} 24^{\prime \prime} \mathrm{W}\right)$, between Puerto Ordaz and Ciudad Bolívar, specifically in front of the island of the Caño Corrientoso. It has a maximum depth of $6.0 \mathrm{~m}$ and a surface area of 25.8 and 23.8 ha. at high and low water, respectively.

Sampling Methodology. Four periods of diurnal and nocturnal collection were done in each lagoon, coinciding with the four hydrological phases, from November 2003 to September 2004. The intention was to describe assemblage composition in the habitat types present.

Two different types of nets were used for sampling different habitats in each lagoon. We used $1 \mathrm{~mm}$ mesh seine nets of $6.5 \mathrm{~m} \times 1.5 \mathrm{~m}$ to collect small fish associated to beach (B) and aquatic vegetation (floating vegetation) (AV), the sampling effort for this gear was standardized to eight tows for each habitat during each hydrological phase.

To collect bigger fish associated to flooded grass fields (FGF), littoral zone and open waters (LZOW), floodplain forests (FF), littoral zone with fallen trunks (LZFT) and rocky outcrops (RO) habitats, we used ten polifilament gill nets of several sizes $(<50 \mathrm{~m}$ of length) and meshes $(5-12.5 \mathrm{~cm})$. These gill nets were placed perpendicular to the margins of the lagoon and were left in the water continuously for 70 hours (being checked for fish individuals every 7 hours) during each hydrological phase. Each revision of the gill nets corresponded to a sampling unit, therefore, sampling effort was standardized to ten sampling in each hydrological phase.

All the fish collected with gill nets were measured (standard length, SL, in millimeters and weight in grams), whereas seined specimens were preserved directly in $10 \%$ formalin to be measured and weighed in the laboratory. Each 
lot of fish was marked according to the different localities (habitats), time, date of sampling, and method of capture. Samples were then labeled and deposited in the EDIHG fish collection (catalog numbers: 3921 to 5660). Duplicates of some species were deposited in the Museo de Historia Natural La Salle, Caracas (MHNLS).

Statistical Analysis. All the analysis depended on the standardization of the fishing methods. These analyses included spatial-temporal comparisons of abundance, biomass, richness (S) and capture per unit effort (CPUE) between habitats and across lagoons. The species abundance was calculated with respect to the total captures of all species in each habitat of each lagoon. The biomass of species was calculated as the percentage of the total weight of all the captures made in each locality or habitat. The richness was catalogued as the number of species present in each lagoon or habitat. The capture per unit effort (CPUE) was defined as: $\mathrm{CPUE}=\mathrm{n} /$ ue; where $\mathrm{n}=\mathrm{N}^{\circ}$ collected fish, and ue $=$ unit effort (Lasso, 1996). As mentioned previously, two systems of fishing (seining and gill netting) were used due to the environmental complexity of each lagoon. In the fishing with gill net, the unit effort was the number of revisions, and in the fishing with fine mesh, the unit effort was number of tows.

We used ANOVAs to evaluate seasonal (falling waters, rising waters, high and low waters) and spatial (between the habitats where the same type of fishing gear was used) variation within and between lagoons. The variables included in the ANOVAs were abundance, biomass and richness. All the data of the variables were transformed to $\log _{10}(x+1)$ and tested for homogeneity of variance (Bartelett's test) and normality (Kolmogorov-Smirnov's test) before applying the ANOVAs. The test of the Least Significant Difference (LSD) was used to determine which averages were different if there were significant differences ( $\mathrm{p}<0.05$ ), Kruskal-Wallis's non parametric statistics was used where any assumption of ANOVA was not met (Sokal \& Rohlf, 1995).

The diversity was analyzed using the index of ShannonWiener (1949). The Shannon-Wiener index, despite underestimating rare species and not being sensitive when species richness $>100$, has been and continues to be one of the more commonly used indices and thus eases comparison with published works.

To assess the seasonal stability of the fish assemblages in each lagoon, we calculated the coefficient of variation (CV), using the relative abundances of the species present in at least 50\% of the collections (Grossman et al., 1990; Langeani et al., 2005). The CV is calculated by dividing the standard deviation by the mean abundance of each species in both lagoons. We used the following arbitrary criteria to classify populations based on their CV's. If $\mathrm{CV} \leq 25 \%=$ assemblages stable; $25 \%<\mathrm{CV} \leq 50 \%=$ moderately stable; $50 \%<\mathrm{CV} \leq 75 \%$ $=$ moderately fluctuating; $\mathrm{CV} \geq 76 \%=$ highly fluctuating (Grossman et al., 1990). The assemblage stability was calculated by examining the mean $\mathrm{CV}$ values of each species in the assemblage as well as for the various collections across the hydrological phases. Also, separate estimates of stability were made for small-size fish (which included young-of-theyear) and for middle to big size fish (mainly adults) of the communities in both lagoons; we distinguished these groups by differences in SL. Such separate estimates are necessary because the inclusion of both groups simultaneously does significantly affect CV values (Freeman et al., 1988; Grossman et al., 1990).

A non-metric multidimensional scaling analysis (nMDS) was used to evaluate seasonal (high and low waters) and spatial (within and between lagoons) differences in the abundance and the composition of the ichthyofauna. The fish assemblages collected with gill net and mesh seine net were analyzed separately because these two sampling gears have different selectivity. For example, the seine usually captures smaller fish (generally $<5 \mathrm{~cm}$ ) but may be less efficient in capturing larger fish. This analysis is a method for bidimensional arrangement which represents relationships among samples in a similarity matrix; this analysis has been considered a robust technique for analyzing ecological data (Clarke \& Warwick, 2001; Langeani et al., 2005; Layman \& Winemiller, 2005). To quantify the similarity among habitats we used the Bray-Curtis distance measure applied to $\log (\mathrm{x}+1)$ transformed data. This analysis was complemented by a analysis of similarities (ANOSIM) (Clarke \& Warwick, 1994), which is a non-parametric analog of MANOVA, in order to evaluate the significant differences that could happen in the species composition among habitat categories (Layman \& Winemiller, 2005). When a significant difference $(\mathrm{p}<0.05)$ was detected, a similarity percentage breakdown (SIMPER) (Clarke \& Warwick, 1994) was conducted to determine which species were primarily responsible (make up $60 \%$ of the difference between factor levels) for the observed difference. This analysis was realized with multivariate analysis software PRIMER 5.

\section{Results}

Spatial and seasonal variation in CPUE. In Las Arhuacas, 38,384 individuals $(229,072 \mathrm{~g})$ were collected during the four hydrological phases and 8,764 individuals (139,688 g) were collected from Los Cardonales. These represented a total of 133 species, grouped into nine orders and 30 families for the first lagoon, and 95 species grouped into nine orders and 25 families for the second lagoon. Of all these species, 55 were exclusive to Las Arhuacas and 17 were exclusive to Los Cardonales. Seventy-seven species were common to both lagoons. Capture per unit effort (CPUE) with beach seine hauls was 37,252 individuals/48 hauls, and 8,171 individuals/64 hauls, for Las Arhuacas and Los Cardonales, respectively. Whereas, the CPUE with gill net was 1.131 individuals/40 revisions and 593 individuals/40 revisions, respectively.

Spatial and seasonal composition of assemblages by habitat. As Fig. 2 show, throughout the hydrological cycle for both 


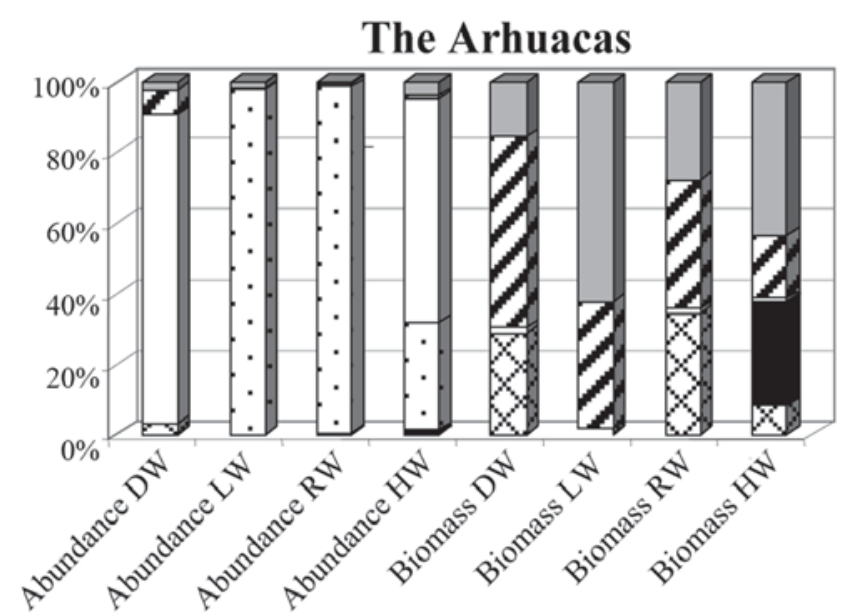

The Cardonales

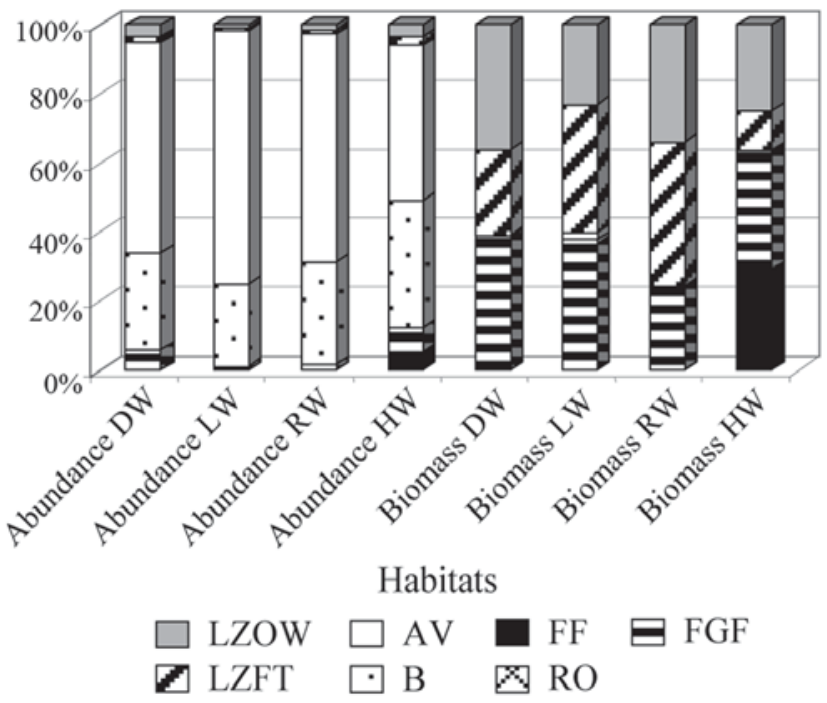

Fig. 2. Percentage distribution abundance and biomass of fish by habitats in each hydrological phase in both lagoons. DW = Descent water, $\mathrm{LW}=$ Low water, RW = Raise water and HW $=$ High water RO $=$ Rocky outcrops, FGF $=$ Flooded grass fields, $\mathrm{FF}=$ Floodplain forests, $\mathrm{B}=$ Beach, $\mathrm{AV}=$ Aquatic vegetation, $\mathrm{LZFT}=$ Littoral zone with fallen trunks and LZOW $=$ Littoral zone and open waters.

lagoons, the highest abundances were in the $\mathrm{AV}$ and $\mathrm{B}$ habitats being most marked in the B habitat of Las Arhuacas during low water ( $98 \%$ porcentage de abundance). In biomass terms, the habitats LZFT, LZOW and FF (present only in high waters) contributed relatively high percentages (> 18\%) in both lagoons during the seasonal cycle. The habitat RO, exclusively present in Las Arhuacas, also accounted for a high percentage (> 29\%) during the transition phases (rising and falling water). The habitat FFG, present in Los Cardonales, contributed high percentages (> 24\%) during the whole hydrological cycle.

In Las Arhuacas lagoon, the orders Characiformes, Siluriformes, Perciformes and Clupeiformes represented more than $90 \%$ of the species (Fig. 3a and b); Characiformes, Siluriformes and Clupeiformes represented $90 \%$ of the species in Los Cardonales lagoon (Fig. 3c and d). Fig. 3 also show that in the beach (B) and aquatic vegetation (AV) habitats (where most collected fish had SL $<5 \mathrm{~cm}$ ) 90\% of the species were represented by Characiformes, Perciformes, Siluriformes and Clupeiformes in Las Arhuacas and by Characiformes, Clupeiformes, Siluriformes and Perciformes in Los Cardonales. In the others habitat (RO, LZFT, LZOW, FF, FFG) (where most of the fish had SL $>5 \mathrm{~cm}$ ), $80 \%$ of the species were Siluriformes, Characiformes, and Perciformes in Laguna Las Arhuacas and Siluriformes, Characiformes, Clupeiformes in Los Cardonales.

Table 1 presents, along with richness, the abundance and relative biomass of each family in each lagoon. There were certain similarities in abundance between the lagoons: the families Clupeidae, Characidae, Loricariidae and Engraulidae accounted for more than $90 \%$ in each lagoon. Biomass was not very similar between the lagoons. Loricariidae, Curimatidae, Characidae and Prochilodontidae, in order of importance, contributed the most biomass (about 60\%) in Las Arhuacas, while Cynodontidae, Doradidae, Pimelodidae, Characidae, Erythrinidae and Auchenipteridae represented $65 \%$ in Los Cardonales. The families with the highest species richness were Characidae, Cichlidae and Loricariidae for Las Arhuacas and, Characidae, Pimelodidae and Engraulidae for Los Cardonales.

ANOVA exploring seasonal and spatial patterns in abundance, biomass and richness of the communities. In general, the abundance, biomass and richness were significantly greater $(\mathrm{p}<0.001)$ in Las Arhuacas (Table 2 , Fig. 4). The application of Kruskal-Wallis test between the habitats sampled with gill net within each lagoon indicated that abundance was significantly higher $(\mathrm{p}<0.05)$ in the habitat LZOW comparative with FF and RO for Las Arhuacas. We also found that, in Los Cardonales, abundance was significantly higher in the habitat FFG than in the habitats LZOW (Fig. 4). In the case of biomass, for both lagoons, there were not significant differences. The richness of species in Las Arhuacas was significantly lower in the habitat RO comparative with LZOW and LZFT. Also, for Los Cardonales, LZFT and LZOW was significantly lower than FGF. In the case of the habitats B and AV sampled with mesh fine net within each lagoon was applied LSD test because the data fulfilled the assumptions of normality and homogeneity of the variances, in these we find only in Los Cardonales, that abundance was significantly higher in $\mathrm{AV}$ than B (Fig. 4).

Comparing the assemblage attributes in the habitats sampled with gill net across the two lagoons, we find that for all the attributes LZOW and LZFT was significantly higher (p $<0.05$ ) for Las Arhuacas. Equally, FF obtained richness significantly higher for Las Arhuacas. In the case of the habitats B and AV, Las Arhuacas obtained abundance and richness significantly higher too (Table 2, Fig. 4). 

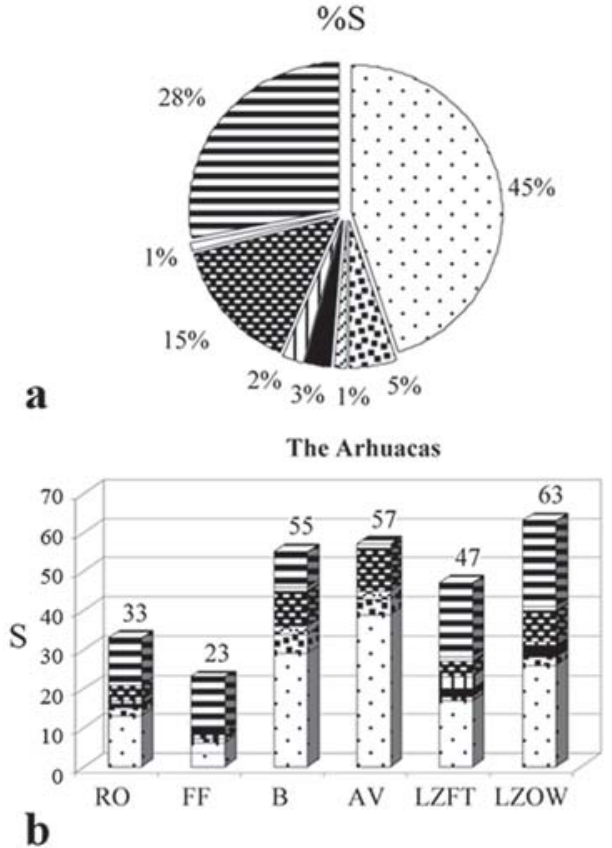
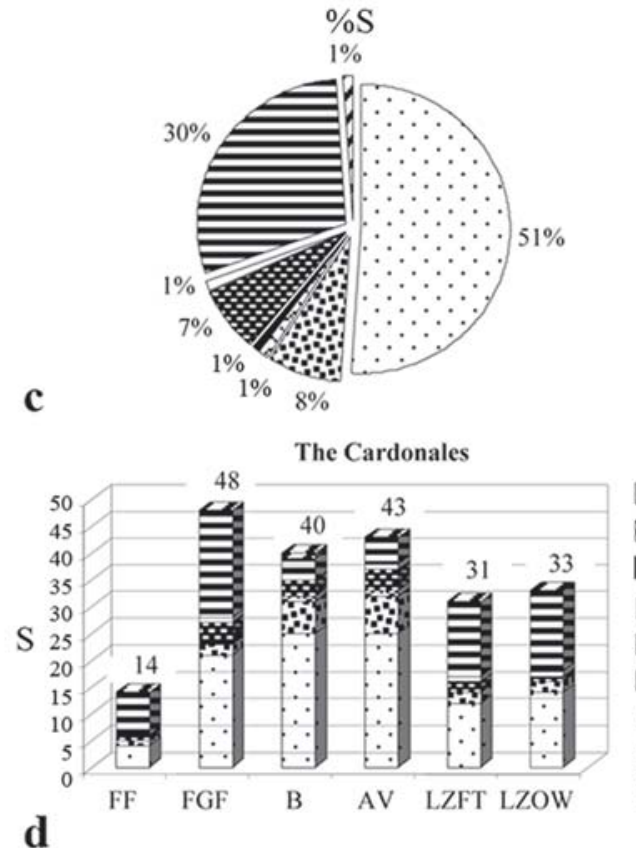

- Characiformes E Siluriformes Gymnotiformes ए Myliobatiformes Perciformes : Clupeiformes ब. Cyprinodontiformes Pleuronectiformes Synbranchiformes

Fig. 3. Percentage abundance of total species (S) and number of species for orders in each habitats of the lagoons. The abbreviations of the habitats are explained in the Fig. 2.

Table 1. Relative abundance (RA), relative biomass (RB) and richness (S) by family in the fish assemblages of the lakes the Arhuacas (Arh) and the Cardonales (Car). "-” = absent family in the corresponding lagoon.

\begin{tabular}{lcccccc}
\hline \multirow{2}{*}{ Family } & \multicolumn{3}{c}{ S } & \multicolumn{2}{c}{ RA } & \multicolumn{2}{c}{ RB } \\
\cline { 2 - 7 } & Arh & Car & Arh & Car & Arh & Car \\
\hline Achiridae & 1 & 1 & 0.07 & 0.11 & 0.17 & 0.14 \\
Anostomidae & 3 & 3 & 0.28 & 0.09 & 5.10 & 1.14 \\
Apteronotidae & 1 & - & 0.00 & - & 0.04 & - \\
Auchenipteridae & 3 & 3 & 0.04 & 0.07 & 0.80 & 0.67 \\
Callichthyidae & - & 1 & - & 0.06 & - & 0.47 \\
Characidae & 33 & 29 & 16.15 & 39.29 & 9.44 & 10.45 \\
Chilodontidae & 1 & 1 & 0.01 & 0.08 & 0.00 & 0.01 \\
Cichlidae & 12 & 5 & 0.18 & 0.82 & 1.44 & 0.66 \\
Clupeidae & 1 & 1 & 70.94 & 47.39 & 0.48 & 0.15 \\
Crenuchidae & 3 & 1 & 0.03 & 0.02 & 1.86 & 0.00 \\
Ctenolucidae & 2 & 1 & 0.01 & 0.17 & 0.16 & 0.43 \\
Curimatidae & 6 & 3 & 1.37 & 0.87 & 16.84 & 9.55 \\
Cynodontidae & 4 & 3 & 3.67 & 0.73 & 3.25 & 12.59 \\
Doradidae & 4 & 4 & 0.07 & 0.64 & 5.57 & 11.41 \\
Engraulidae & 5 & 6 & 0.33 & 5.99 & 0.08 & 0.24 \\
Erythrinidae & 2 & 1 & 0.05 & 0.47 & 2.17 & 10.05 \\
Gymnotidae & 1 & - & 0.00 & - & 1.44 & - \\
Gobiidae & 1 & - & 0.09 & - & 0.00 & - \\
Hemiodontidae & 2 & 3 & 0.01 & 0.06 & 0.19 & 0.16 \\
Lebiasinidae & 2 & - & 0.02 & - & 0.00 & - \\
Loricariidae & 13 & 7 & 6.01 & 1.05 & 22.57 & 9.32 \\
Nandidae & 1 & - & 0.00 & - & 0.00 & - \\
Pimelodidae & 15 & 11 & 0.14 & 1.04 & 6.78 & 20.48 \\
Poeciliidae & 1 & 1 & 0.11 & 0.24 & 0.00 & 0.00 \\
Potamotrygonidae & 3 & - & 0.03 & - & 3.30 & - \\
Pristigasteridae & 1 & 1 & 0.03 & 0.23 & 2.18 & 4.50 \\
Prochilodontidae & 3 & 3 & 0.18 & 0.33 & 9.37 & 2.68 \\
Rhamphichthyidae & - & 1 & - & 0.01 & - & 0.11 \\
Rivulidae & 1 & - & 0.05 & - & 0.00 & - \\
Sciaenidae & 4 & 2 & 0.07 & 0.21 & 6.20 & 4.80 \\
Sternopygidae & 2 & - & 0.03 & - & 0.54 & - \\
Synbranchidae & - & 1 & - & 0.01 & - & 0.00 \\
Trichomycteridae & 2 & 2 & 0.04 & 0.02 & 0.00 & 0.00 \\
\hline
\end{tabular}

The application of Kruskal-Wallis test to the variance of the assemblage attributes between hydrological phases within each lagoon showed that in Las Arhuacas there were significantly higher $(\mathrm{p}<0.05)$ values of richness during low waters (LW), dropping water (DW) and rising water (RW) in relation to high waters (HW). For Los Cardonales, the abundance and richness was significantly lower $(\mathrm{p}<0.05)$ during HW with respect to DW (Fig. 4).

Fish assemblage stability or variability. The majority of the species were small and most of these showed generally high values of CV (CV values usually ranging between 60 and $160 \%$ ) throughout the hydrological cycle and therefore were classified as highly fluctuating (Matthews, 1998), showing a general absence of stability at the population level (Table 3). The CVs of total abundance per collections for middle-sized to large fish (captured with gill nets) appeared more stable or less variable through the hydrological phases in Los Cardonales than Las Arhuacas (Table 4). For example, the CVs of total abundance for Los Cardonales ranged between 48,4 and 97,2\% (median 60,8\%) and 46,5 and 79,0\% (median 61,75\%) for Las Arhuacas.

Consequently, the CVs values in Los Cardonales indicate moderately stable adult fishes assemblages (excepting DW with CV values 97,2\%). Fish assemblage in Las Arhuacas was moderately fluctuating in HW and DW, moderately stable in LW and highly fluctuating in RW (Table 4). The CVs of total abundance per collections for small-size fishes (captures with fine mesh nets) demonstrated bigger seasonal fluctuations that produced CVs of 84 to $134 \%$ computed across all samples in both lagoons (Table 5). 
Table 2. Result of variance analysis (F) and of Kruskal-Wallis test (H) for abundance (Abund), biomass (Biom) and richess (Rich), according to seasonal and spatial (between the habitats where the same type of fishing gear was used) variation within and between lagoons (Card = Cardonales and Arh = Arhuacas). NS = non-significant difference; $* *=$ significant difference at the level of $\mathrm{p}<0.01$; $^{*}=$ significant difference at the level of $\mathrm{p}<0.05$.

\begin{tabular}{|c|c|c|c|c|c|c|c|c|c|}
\hline \multirow[t]{2}{*}{ Factors } & \multicolumn{2}{|c|}{ Lagoons } & \multicolumn{2}{|c|}{$\begin{array}{l}\text { Hidrological } \\
\text { phases }\end{array}$} & \multicolumn{2}{|c|}{$\begin{array}{l}\text { Habitats } \\
\text { (gill net) }\end{array}$} & \multicolumn{2}{|c|}{$\begin{array}{c}\text { Habitats } \\
\text { (fine mesh net) }\end{array}$} & \multirow[t]{2}{*}{ a posteriori Test } \\
\hline & $\mathrm{H}$ & $\mathrm{p}$ & $\mathrm{H}$ & $p$ & $\mathrm{H}$ & $p$ & $\mathrm{~F}$ & $p$ & \\
\hline Abund Arh & & & 1.63 & $0.65 \mathrm{NS}$ & & & & & \\
\hline Abund Card & & & 7.95 & $0.04 *$ & & & & & $\mathrm{HW}<\mathrm{DW}=\mathrm{LW}=\mathrm{RW}$ \\
\hline Abund Card X Arh & 27.5 & $0.00 * *$ & & & & & & & Arh $>$ Car \\
\hline Abund Card X Arh DW & & & 2.19 & $0.13 \mathrm{NS}$ & & & & & \\
\hline Abund Card X Arh RW & & & 7.69 & $0.00 * *$ & & & & & Arh $>$ Car \\
\hline Abund Card X Arh LW & & & 6.68 & $0.00 * *$ & & & & & Arh $>$ Car \\
\hline Abund Card X Arh HW & & & 10.47 & $0.00 * *$ & & & & & Arh $>$ Car \\
\hline Abund Card X Arh FF & & & & & 1.18 & $0.27 \mathrm{NS}$ & & & \\
\hline Abund Card X Arh ZLOW & & & & & 35.88 & $0.00^{* *}$ & & & Arh $>$ Car \\
\hline Abund Card X Arh ZLFT & & & & & 21.46 & $0.00 * *$ & & & Arh $>$ Car \\
\hline Abund Card X Arh B & & & & & & & 22.20 & $0.00 * *$ & Arh $>$ Car \\
\hline Abund Card X Arh AV & & & & & & & 7.12 & $0.01^{*}$ & Arh $>$ Car \\
\hline Biom Arh & & & 4.73 & $0.19 \mathrm{NS}$ & & & & & \\
\hline Biom Card & & & 4.13 & $0.25 \mathrm{NS}$ & & & & & \\
\hline Biom Card X Arh & 18.3 & $0.00^{* *}$ & & & & & & & Arh $>$ Car \\
\hline Biom Card X Arh DW & & & 7.65 & $0.00 * *$ & & & & & Arh $>$ Car \\
\hline Biom Card X Arh RW & & & 4.60 & $0.03^{*}$ & & & & & Arh $>$ Car \\
\hline Biom Card X Arh LW & & & 7.04 & $0.00 * *$ & & & & & Arh $>$ Car \\
\hline Biom Card X Arh HW & & & 0.80 & $0.37 \mathrm{NS}$ & & & & & \\
\hline Biom Card X Arh FF & & & & & 0.52 & $0.47 \mathrm{NS}$ & & & \\
\hline Biom Card X Arh ZLOW & & & & & 17.37 & $0.00^{* *}$ & & & Arh $>$ Car \\
\hline Biom Card X Arh ZLFT & & & & & 12.88 & $0.00 * *$ & & & Arh $>$ Car \\
\hline Biom Card X Arh B & & & & & & & 4.62 & $0.03^{*}$ & Arh $>$ Car \\
\hline Biom Card X Arh AV & & & & & & & 4.24 & $0.04 *$ & Arh $>$ Car \\
\hline Rich Arh & & & 18.05 & $0.00 * *$ & & & & & $\mathrm{HW}<\mathrm{RW}=\mathrm{LW}=\mathrm{DW}$ \\
\hline Rich Card & & & 12.29 & $0.00 * *$ & & & & & $\mathrm{DW}>\mathrm{RW}=\mathrm{LW}=\mathrm{HW}$ \\
\hline Rich Card X Arh & 35.7 & $0.00 * *$ & & & & & & & Arh $>$ Car \\
\hline Rich Card X Arh DW & & & 2.36 & $0.12 \mathrm{NS}$ & & & & & \\
\hline Rich Card X Arh RW & & & 14.47 & $0.00 * *$ & & & & & Arh $>$ Car \\
\hline Rich Card X Arh LW & & & 17.69 & $0.00 * *$ & & & & & Arh $>$ Car \\
\hline Rich Card X Arh HW & & & 6.91 & $0.00 * *$ & & & & & Arh $>$ Car \\
\hline Rich Card X Arh FF & & & & & 3.95 & $0.04 *$ & & & Arh $>$ Car \\
\hline Rich Card X Arh ZLOW & & & & & 27.54 & $0.00 * *$ & & & Arh $>$ Car \\
\hline Rich Card X Arh ZLFT & & & & & 19.34 & $0.00 * *$ & & & Arh $>$ Car \\
\hline Rich Card X Arh B & & & & & & & 7.21 & $0.00^{* *}$ & \\
\hline Rich Card X Arh AV & & & & & & & 10.71 & $0.00 * *$ & Arh $>$ Car \\
\hline
\end{tabular}

Diversity, equitability and richness of the assemblages. Diversity (H') was highest in Los Cardonales ( 0.86 versus 0.57 in Las Arhuacas) due to the higher equitability in this lagoon (0.43 versus 0.26 in Las Arhuacas). This occurred despite the fact that Las Arhuacas had the highest richness. With respect to hydrological phases, the highest diversity, equitability and richness in both lagoons (Fig. 5a and c) occurred during DW; whereas the lowest values of richness and diversity (including equitability) happened in HW and LW (for Las Arhuacas) or in LW and RW (for Los Cardonales). The Fig. $5 b$ and $d$ show the indices of diversity, equitability and richness in the different habitats of each lagoon. In both lagoons, low values of diversity and equitability occurred in the $\mathrm{B}$ and $\mathrm{AV}$ habitats. The rest of the habitats (RO, FFG, FF, LZFT and LZOW) showed relatively high values of diversity and equitability in the two lagoons with the LZFT habitat having the highest value in Las Arhuacas and the FFG habitat being highest in Los Cardonales.
Similarity and seasonal-spatial variability in fish assemblages at habitat level. The non-metric multidimensional analysis (nMDS) showed spatial segregation among habitats, and recognized two characteristic species assemblages for both lagoons. That is to say, assemblage composition was significantly different among habitats of both lagoons during both high waters (HW) (ANOSIM, $\mathrm{p}<0.05$ ) and low waters (LW) (ANOSIM, $\mathrm{p}<0.001$; Table 6, Fig. 6).

Also, pair-wise comparisons revealed significant differences between almost all habitat pairs with the differences being higher during LW (ANOSIM, all p < 0.001). There were exceptions in that some pairs showed no significant difference, these included LZOWcar versus LZFTcar; FFcar with FFarh and LZOWarh in HW and LZFTcar with LZOWcar in LW. Also, there were differences in the composition of assemblages when comparing AVcar with Bcar in both hydrological phases ( $>>0.05)$. Likewise, the nMDS ordination suggested slightly more structured 

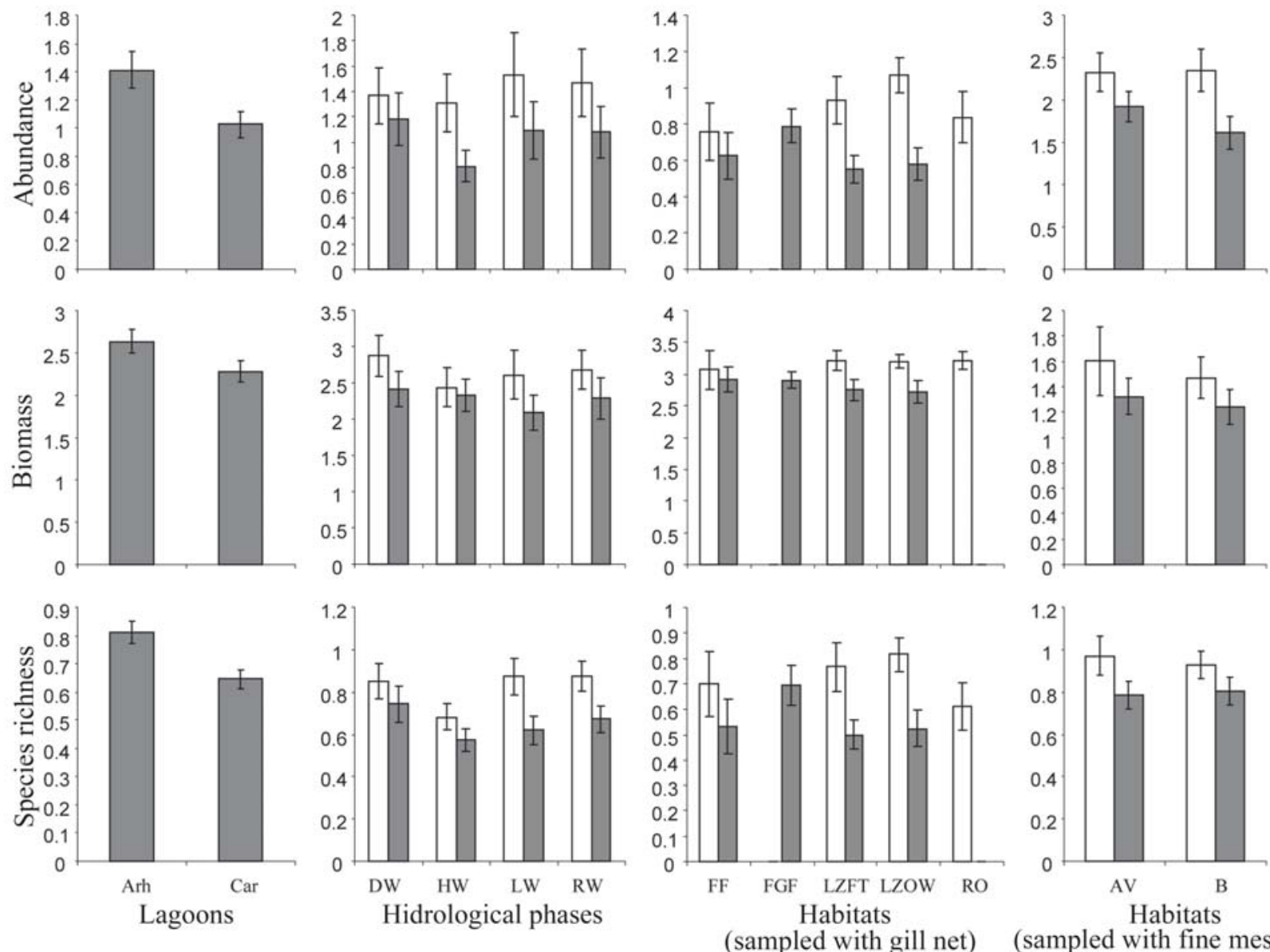

(sampled with gill net)

(sampled with fine mesh net)

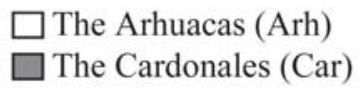

Fig. 4. Mean values ( \pm confidence interval) of abundance, biomass and richness by habitats and hydrological phases between lagoons. The abbreviations of the hydrological phases and habitats are explained in the Fig. 2 .

communities (i.e., higher similarity in the composition among habitats within each lagoon) with less variability for LW samples.

The SIMPER analysis identified the species that were most common in each habitat. For example, the Table 7 revealed for the captures with gill net during HW in Las Arhuacas that Hypostomus argus was the specie more commonly collected in the Rocky outcrops (RO); Aphanotorulus ammophilus, Pellona flavipinnis and Hypophthalmus edentatus in Floodplain forests (FF); Potamorhina altamazonica, Pygocentrus cariba and Trachelyopterus galeatus in littoral zone and open waters (LZOW); Prochilodus mariae, Triportheus venezuelensis, Loricaria cataphracta, Hydrolycus armatus, Mylossoma duriventre and Loricariichthys brunneus in littoral zone with fallen trunks (LZFT). In Los Cardonales during HW, $P$. altamazonica and $H$. armatus were more commonly collected in flooded field of grass (FFG); H. edentatus and $P$. flavipinnis in FF; Pterygoplichthys multiradiatus, $H$. argus and Plagioscion squamosissimus in LZFT; Oxydoras sifontesi, Pterodoras rivasi, Hoplias malabaricus and $P$. cariba in LZOW.

During LW for Las Arhuacas, Mylossoma duriventre was the specie more common for RO; $H$. argus, $P$. squamosissimus, P. mariae, H. malabaricus and Potamotrygon sp. 1 in LZFT; P. altamazonica, Psectrogaster ciliata, Loricariichthys brunneus, L. cataphracta, T. venezuelensis, Loricaria sp. 1 and Sternopygus macrurus in LZOW. While, for Los Cardonales H. argus and H. malabaricus in LZFT; P. mariae, H. armatus, Pseudoplatystoma metaense, Colossoma macropomum and Caquetaia kraussii were more commonly in FFG; Pterodoras rivasi, P. squamosissimus, Piaractus brachypomus, and $O$. sifontesi in LZOW.

In the case of small-size fishes (Table 8), during HW for Las Arhuacas, Moenkhausia sp. 1 "lepidura", Rachovia maculipinnis and Curimatella dorsalis were the species more commonly collected in beach (B) and Aphyocharax alburnus, Characidium sp. 1, T. venezuelensis (young), Hemigrammus sp. 3 aff. micropterus, Odontostilbe pulchra and Astyanax bimaculatus in aquatic vegetation (AV). In Los Cardonales, 
Table 3. Values of relative abundance during the hydrological phases, mean abundance and coefficients of variation (CV\%) by species present in at least $50 \%$ of collections in both lagoons. Arh $=$ The Arhuacas and Car $=$ The Cardonales. "a" = species absents in the lagoon respective and “-” = present species with values $<50 \%$ in the collections. "a” = small-size fish.

\begin{tabular}{|c|c|c|c|c|c|c|c|}
\hline \multirow{2}{*}{ Species } & & \multicolumn{4}{|c|}{ Hidrological phases } & \multirow{2}{*}{ Mean abundance } & \multirow{2}{*}{ CV of abundace } \\
\hline & & HW & LW & DW & RW & & \\
\hline \multirow{2}{*}{ Achirus novoae ${ }^{a}$} & Arh & 0 & 2 & 3 & 20 & 6.25 & 148.0 \\
\hline & Car & 1 & 0 & 1 & 8 & 2.5 & 147.9 \\
\hline \multirow{2}{*}{ Aequidens sp. "Llanos" } & Arh & 4 & 2 & 1 & 5 & 3 & 60.9 \\
\hline & Car & 3 & 9 & 14 & 1 & 6.75 & 87.5 \\
\hline \multirow{2}{*}{ Anchoviella lepidentostole ${ }^{a}$} & Arh & - & - & - & - & - & - \\
\hline & Car & 45 & 132 & 0 & 5 & 45.5 & 134.2 \\
\hline \multirow{2}{*}{ Anchoviella perezi ${ }^{a}$} & Arh & 3 & 2 & 2 & 1825 & 458 & 199.0 \\
\hline & Car & 6 & 55 & 221 & 29 & 77.75 & 125.5 \\
\hline Aphyocharax alburnus ${ }^{a}$ & Arh & 6 & 46 & 575 & 24 & 162.75 & 169.2 \\
\hline Apnyocnarax aidurnus & Car & 12 & 174 & 282 & 34 & 125.5 & 100.9 \\
\hline Caguetaia kraussij & Arh & - & - & - & - & - & - \\
\hline Caquetala kraussil & Car & 6 & 18 & 12 & 5 & 10.25 & 58.7 \\
\hline Characidium cf, zebra ${ }^{a}$ & Arh & 0 & 12 & 60 & 15 & 21.75 & 121.0 \\
\hline & Car & - & - & - & - & - & - \\
\hline Cheirodontops geayi $^{a}$ & Arh & 0 & 18 & 0 & 160 & 44.5 & 174.1 \\
\hline 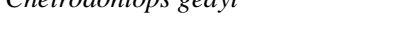 & Car & - & - & - & - & - & - \\
\hline Colossoma macropomun & Arh & 3 & 0 & 2 & 2 & 1.75 & 71.9 \\
\hline coiossoma тасторотип & Car & 1 & 8 & 8 & 5 & 5.5 & 60.3 \\
\hline Exodon naradoxus & Arh & - & - & - & - & - & - \\
\hline Exociont paraudus & Car & 19 & 0 & 3 & 0 & 5.5 & 165.6 \\
\hline Hemigrammus sp. $1^{a}$ & Arh & 1 & 67 & 55 & 292 & 103.75 & 124.1 \\
\hline 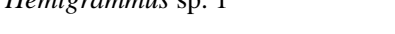 & Car & 0 & 25 & 45 & 2 & 18 & 118.2 \\
\hline Hoplias malabaricus & Arh & 6 & 2 & 6 & 5 & 4.75 & 39.9 \\
\hline & Car & 0 & 7 & 28 & 6 & 10.25 & 119.3 \\
\hline & Arh & 1 & 2 & 15 & 5 & 5.75 & 111.2 \\
\hline Hyarollcus armatus & Car & 5 & 6 & 24 & 22 & 14.25 & 71.2 \\
\hline Hypopthalmus edentatus & Arh & 8 & 0 & 1 & 3 & 3 & 118.6 \\
\hline нурортпаттиз еaеntatus & Car & 12 & 1 & 18 & 6 & 9.25 & 79.6 \\
\hline Hypostomus plecostomoides & Arh & 2 & 0 & 1 & 6 & 2.25 & 116.9 \\
\hline пуровiomus piecostomolaes & Car & a & $\mathrm{a}$ & $\mathrm{a}$ & $\mathrm{a}$ & $\mathrm{a}$ & $\mathrm{a}$ \\
\hline Hunostomus nlecostomus & Arh & 6 & 13 & 107 & 58 & 46 & 101.6 \\
\hline нуровtomus piecostomus & Car & 2 & 18 & 15 & 18 & 13.25 & 57.6 \\
\hline Loricaria sp. 2 & Arh & 2 & 4 & 1 & 9 & 4 & 89.0 \\
\hline Lortedirta sp. 2 & Car & a & $\mathrm{a}$ & $\mathrm{a}$ & $\mathrm{a}$ & $\mathrm{a}$ & $\mathrm{a}$ \\
\hline Loricaria cataphracta & Arh & 1 & 25 & 10 & 16 & 13 & 77.7 \\
\hline LOTाE & Car & a & $\mathrm{a}$ & $\mathrm{a}$ & a & a & $\mathrm{a}$ \\
\hline Loricariichthvs brunneus & Arh & 0 & 7 & 5 & 33 & 11.25 & 131.5 \\
\hline Loricarticntnys orunieus & Car & 1 & 3 & 3 & 3 & 2.5 & 40.0 \\
\hline Moenkhausia sp. 1 "gr. lepidura"a & Arh & 3827 & 64 & 273 & 94 & 1064.5 & 173.2 \\
\hline & Car & $\mathrm{a}$ & $\mathrm{a}$ & $\mathrm{a}$ & $\mathrm{a}$ & $\mathrm{a}$ & $\mathrm{a}$ \\
\hline Moenkhausia sp. $2^{a}$ & Arh & $\mathrm{a}$ & $\mathrm{a}$ & $\mathrm{a}$ & $\mathrm{a}$ & $\mathrm{a}$ & $\mathrm{a}$ \\
\hline Muoenknausia sp. 2 & Car & 449 & 449 & 894 & 184 & 494 & 59.6 \\
\hline Moenkhausia sp. $3^{a}$ & Arh & 0 & 46 & 1 & 8 & 13.75 & 158.5 \\
\hline & Car & 0 & 257 & 154 & 69 & 120 & 92.5 \\
\hline Mylossoma duriventre & Arh & 0 & 2 & 8 & 43 & 13.25 & 151.9 \\
\hline Mryiossoma aurtventre & Car & - & - & - & - & - & - \\
\hline Odontostilbe pulchra ${ }^{a}$ & Arh & 6 & 197 & 625 & 550 & 344.5 & 85.0 \\
\hline 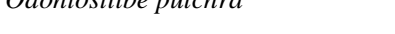 & Car & 0 & 11 & 13 & 2 & 6.5 & 99.3 \\
\hline Oxydoras niger & Arh & 0 & 5 & 6 & 3 & 3.5 & 75.6 \\
\hline Oxyuor us mityer & Car & 1 & 6 & 3 & 14 & 6 & 95.3 \\
\hline Pellona flavipinnis & Arh & 10 & 1 & 1 & 0 & 3 & 156.3 \\
\hline & Car & 14 & 1 & 5 & 1 & 5.25 & 116.8 \\
\hline Piaractus brachypomum & Arh & 0 & 2 & 9 & 3 & 3.5 & 110.7 \\
\hline Plaractus oracnypomum & Car & 3 & 1 & 9 & 1 & 3.5 & 108.2 \\
\hline Plagioscion squamosissimus & Arh & 4 & 2 & 6 & 5 & 4.25 & 40.2 \\
\hline Plagiosciont squamosisstmus & Car & 0 & 3 & 6 & 6 & 3.75 & 76.6 \\
\hline Potamorhina altamazonica & Arh & 148 & 51 & 13 & 24 & 59 & 104.1 \\
\hline & Car & 50 & 0 & 8 & 11 & 17.25 & 129.4 \\
\hline Petamotryagn sn 1 & Arh & 0 & 3 & 1 & 5 & 2.25 & 98.5 \\
\hline Foramori y goil sp. 1 & Car & a & $\mathrm{a}$ & a & $\mathrm{a}$ & $\mathrm{a}$ & $\mathrm{a}$ \\
\hline Pristella maxillaris ${ }^{a}$ & Arh & 0 & 13 & 0 & 26 & 9.75 & 127.7 \\
\hline Prtsienta maxmints & Car & a & $\mathrm{a}$ & $\mathrm{a}$ & a & $\mathrm{a}$ & $\mathrm{a}$ \\
\hline Prochilodus mariae & Arh & 0 & 14 & 31 & 15 & 15 & 84.5 \\
\hline Procnitoaus martae & Car & 0 & 6 & 13 & 3 & 5.5 & 101.2 \\
\hline Psectrogaster ciliata & Arh & 3 & 17 & 1 & 24 & 11.25 & 98.5 \\
\hline Psectroguster citlata & Car & - & - & - & - & - & - \\
\hline Pseudoplatystoma tiarinum & Arh & - & - & - & - & - & - \\
\hline & Car & 1 & 0 & 13 & 2 & 4 & 151.4 \\
\hline Pterodoras rivasi & Arh & - & - & - & - & - & - \\
\hline & Car & 14 & 3 & 4 & 4 & 6.25 & 83.0 \\
\hline Pterygoplichthys multiradiatus & Arh & 3 & 1 & 1 & 0 & 1.25 & 100.7 \\
\hline & Car & 2 & 5 & 5 & 8 & 5 & 49.0 \\
\hline
\end{tabular}


Table 3. Cont.

\begin{tabular}{|c|c|c|c|c|c|c|c|}
\hline \multirow{2}{*}{ Pygocentrus cariba } & Arh & 1 & 4 & 17 & 3 & 6.25 & 116.4 \\
\hline & Car & 0 & 5 & 3 & 9 & 4.25 & 88.8 \\
\hline \multirow{2}{*}{ Rhinosardinia amazonica ${ }^{a}$} & Arh & 0 & 10727 & 0 & 16503 & 6807.5 & 120.6 \\
\hline & Car & 1 & 1515 & 375 & 2262 & 1038.25 & 100.1 \\
\hline \multirow{2}{*}{ Roeboides dientonito $^{a}$} & Arh & - & - & - & - & - & - \\
\hline & Car & 0 & 79 & 6 & 80 & 41.25 & 107.2 \\
\hline \multirow{2}{*}{ Semaprochilodus laticeps } & Arh & 1 & 2 & 3 & 6 & 3 & 72.0 \\
\hline & Car & - & - & - & - & - & - \\
\hline \multirow{2}{*}{ Sternopygus macrurus } & Arh & 0 & 5 & 1 & 2 & 2 & 108.0 \\
\hline & Car & $\mathrm{a}$ & a & $\mathrm{a}$ & $\mathrm{a}$ & $\mathrm{a}$ & $\mathrm{a}$ \\
\hline \multirow{2}{*}{ Trachelyopterus cf. galeatus } & Arh & 8 & 1 & 3 & 0 & 3 & 118.6 \\
\hline & Car & - & - & - & - & - & - \\
\hline \multirow{2}{*}{ Triportheus venezuelensis } & Arh & 21 & 15 & 87 & 17 & 35 & 99.3 \\
\hline & Car & 3 & 8 & 26 & 0 & 9.25 & 125.9 \\
\hline
\end{tabular}

Table 4. Values of relative abundance per collections with gill nets, mean abundance and coefficients of variation (CV\%) during the hydrological phases in both lagoons. Samp. = sampling.

\begin{tabular}{|c|c|c|c|c|c|c|c|c|c|c|c|c|c|}
\hline & $\begin{array}{l}\text { Hydrological } \\
\text { phases }\end{array}$ & Samp.1 & Samp.2 & Samp.3 & Samp.4 & Samp.5 & Samp.6 & Samp.7 & Samp.8 & Samp.9 & Samp.10 & $\begin{array}{c}\text { Mean } \\
\text { abundance }\end{array}$ & $\begin{array}{c}\text { CV of } \\
\text { abundace }\end{array}$ \\
\hline \multirow{4}{*}{ Arh } & HW & 44 & 34 & 14 & 4 & 45 & 33 & 9 & 14 & 48 & 7 & 25.2 & 68.7 \\
\hline & LW & 40 & 41 & 22 & 10 & 20 & 21 & 18 & 14 & 29 & 14 & 22.9 & 46.5 \\
\hline & DW & 61 & 41 & 23 & 35 & 53 & 25 & 24 & 32 & 12 & 9 & 31.5 & 52.8 \\
\hline & RW & 97 & 62 & 18 & 13 & 29 & 18 & 20 & 37 & 23 & 18 & 33.5 & 79.0 \\
\hline \multirow{4}{*}{ Car } & HW & 21 & 27 & 12 & 10 & 9 & 13 & 11 & 6 & 11 & 9 & 12.9 & 49.0 \\
\hline & LW & 11 & 15 & 7 & 4 & 8 & 10 & 5 & 4 & 4 & 12 & 8.0 & 48.6 \\
\hline & DW & 80 & 62 & 16 & 10 & 18 & 14 & 6 & 16 & 14 & 18 & 25.4 & 97.2 \\
\hline & RW & 17 & 23 & 12 & 6 & 11 & 10 & 22 & 7 & 7 & 11 & 12.6 & 48.4 \\
\hline
\end{tabular}

Table 5. Values of relative abundance per collections with fine mesh nets ( $\mathrm{AV}=$ aquatic vegetation and $\mathrm{B}=$ beach), mean abundance and coefficients of variation (CV\%) during the hydrological phases in both lagoons. To = tows and "-" = habitat absent in the phase respective.

\begin{tabular}{|c|c|c|c|c|c|c|c|c|c|c|c|c|c|c|c|c|c|c|c|}
\hline & Hydrological & AV & AV & $\mathrm{AV}$ & $\mathrm{AV}$ & $\mathrm{AV}$ & AV & $\mathrm{AV}$ & $\mathrm{AV}$ & B & B & B & B & B & B & B & B & Mean & $\begin{array}{l}\text { CV of } \\
\text { abundace }\end{array}$ \\
\hline & phases & To.1 & To. 2 & To.3 & To.4 & To.5 & To.6 & To.7 & To.8 & To.1 & To.2 & To.3 & To.4 & To.5 & To.6 & To.7 & To.8 & abundance & abundace \\
\hline \multirow{4}{*}{ Arh } & HW & 154 & 326 & 226 & 98 & 112 & 450 & 756 & 520 & 66 & 180 & 492 & 309 & 77 & 91 & 53 & 63 & 248.3 & 84.2 \\
\hline & LW & - & - & - & - & - & - & - & - & 1146 & 195 & 87 & 499 & 224 & 3143 & 4537 & 1438 & 1408.6 & 114.8 \\
\hline & DW & 423 & 252 & 582 & 209 & 627 & 57 & 49 & 63 & - & - & - & - & - & - & - & - & 282.8 & 83.3 \\
\hline & RW & - & - & - & - & - & - & - & - & 1209 & 1006 & 5995 & 319 & 8194 & 1783 & 739 & 503 & 2468.5 & 119.5 \\
\hline \multirow{4}{*}{ Car } & HW & 30 & 60 & 22 & 13 & 69 & 31 & 72 & 39 & 19 & 12 & 8 & 162 & 39 & 8 & 12 & 15 & 38.2 & 102.6 \\
\hline & LW & 41 & 84 & 17 & 62 & 171 & 142 & 84 & 575 & 31 & 73 & 5 & 4 & 178 & 10 & 46 & 469 & 124.5 & 133.1 \\
\hline & DW & 24 & 122 & 214 & 504 & 54 & 274 & 192 & 20 & 80 & 149 & 11 & 12 & 98 & 94 & 132 & 69 & 128.1 & 98.3 \\
\hline & RW & 524 & 97 & 140 & 896 & 50 & 27 & 55 & 83 & 102 & 124 & 62 & 254 & 99 & 115 & 27 & 58 & 169.6 & 134.6 \\
\hline
\end{tabular}
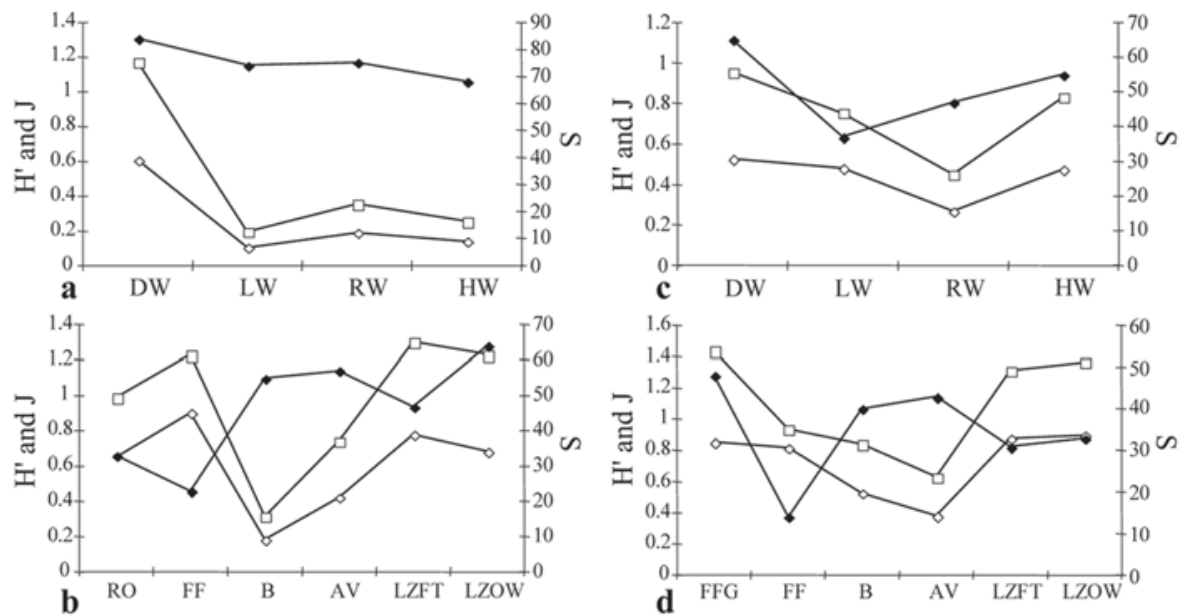

\section{Legend}

Richness (S) $\quad \longrightarrow$ - Shanon's diversity ( $\left.\mathrm{H}^{\prime}\right) \quad \prec$ Shanon's equitability (J)

Fig. 5. Variability by hydrological phases and habitats of the diversity and equitability (Shanon) and richness. $a$ and $b=$ the Arhuacas; $\mathrm{c}$ and $\mathrm{d}=$ the Cardonales. The abbreviations of the hydrological phases and habitats are explained in the Fig. 2. 
Table 6. Analysis of disimilarity (ANOSIM; 1999 permutations) between habitats. $\mathrm{a}=$ gill nets sampling and $\mathrm{b}=$ seine net sampling, in both lagoons during high waters ( $\mathrm{a}: \mathrm{r}^{2}=0.469 ; \mathrm{p}<0.05$ and $\left.\mathrm{b}: \mathrm{r}^{2}=0.469 ; \mathrm{p}<0.05\right)$ and low waters $\left(\mathrm{a}: \mathrm{r}^{2}=0.567 ; \mathrm{p}\right.$ $<0.001$ and b: $\mathrm{r}^{2}=0.599 ; \mathrm{p}<0.001$ ) based on the composition of species. $*=$ Significant difference at $\mathrm{p}<0.05$; arh $=$ Las Arhuacas and car $=$ Los Cardonales. The abbreviations of the habitats are explained in the Fig. 2.

\begin{tabular}{|c|c|c|c|c|c|c|c|c|c|c|c|c|c|c|c|}
\hline \multirow{2}{*}{ (a) } & & \multicolumn{8}{|c|}{ High water } & \multirow{2}{*}{\multicolumn{2}{|c|}{ (b) }} & \multicolumn{4}{|c|}{ High water } \\
\hline & & ROarh & FFarh & LZOWarh & ZLTCarh & FFcar & FFGcar & LZFTcar & LZOWcar & & & Barh & AVarh & Bcar & AVacar \\
\hline \multirow{8}{*}{ 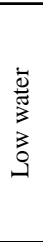 } & ROarh & - & $0.326 *$ & $0.414^{*}$ & $0.422 *$ & $0.385 *$ & $0.664 *$ & $0.363 *$ & $0.485^{*}$ & $\check{\Xi}$ & Barh & - & $0.444 *$ & $0.889 *$ & $0.828 *$ \\
\hline & FFarh & - & - & $0.286 *$ & $0.424 *$ & 0.129 & $0.514 *$ & $0.335^{*}$ & $0.438 *$ & $\frac{\pi}{3}$ & AVarh & - & - & $0.773 *$ & $0.703^{*}$ \\
\hline & LZOWarh & $0.907 *$ & - & - & $0.273 *$ & 0.192 & $0.353 *$ & $0.247^{*}$ & $0.508 *$ & 3 & Bcar & $0.853 *$ & - & - & 0.007 \\
\hline & ZLTCarh & $0.4 *$ & - & $0.486 *$ & - & $0.463 *$ & $0.631 *$ & $0.358 *$ & $0.619 *$ & O & AVacar & $0.745^{*}$ & - & 0.111 & - \\
\hline & FFcar & - & - & - & - & - & $0.211^{*}$ & 0.219 & $0.330 *$ & & & & & & \\
\hline & FFGcar & $0.732 *$ & - & $0.709 *$ & $0.574 *$ & - & - & $0.300 *$ & $0.535 *$ & & & & & & \\
\hline & LZFTcar & $0.506 *$ & - & $0.765 *$ & $0.378 *$ & - & $0.367 *$ & - & 0.1 & & & & & & \\
\hline & LZOWcar & $0.531 *$ & - & 0.766* & $0.228 *$ & - & $0.445 *$ & 0.019 & - & & & & & & \\
\hline
\end{tabular}

\section{High water}
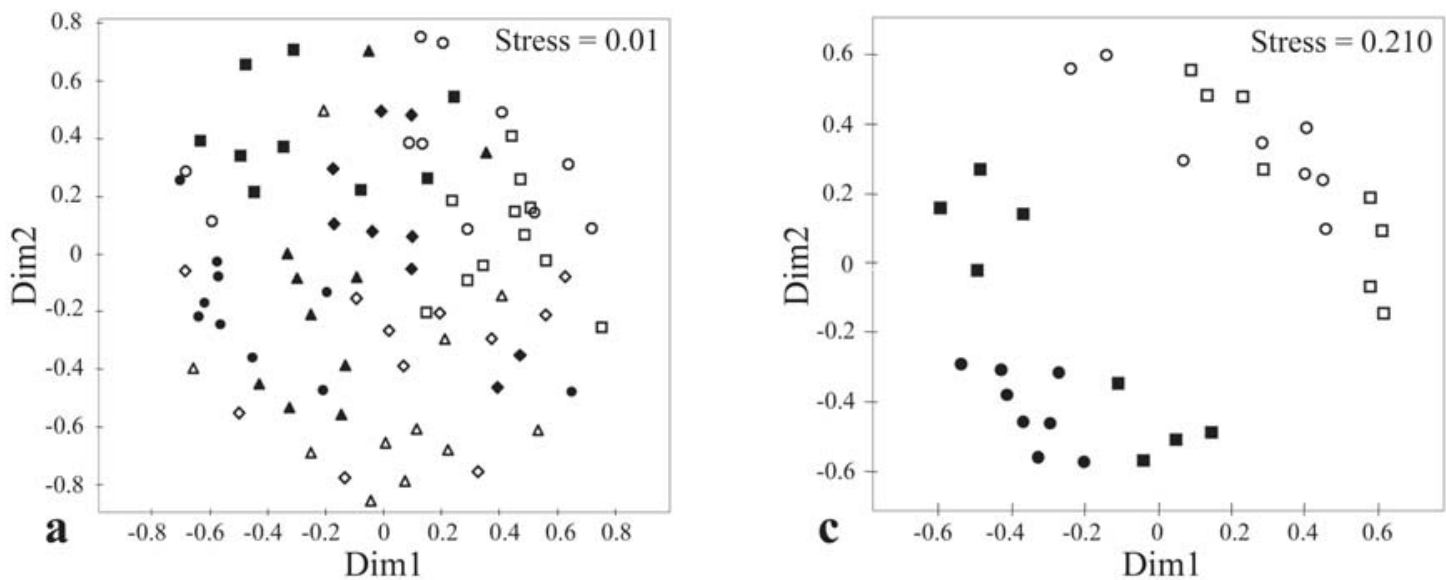

Low water

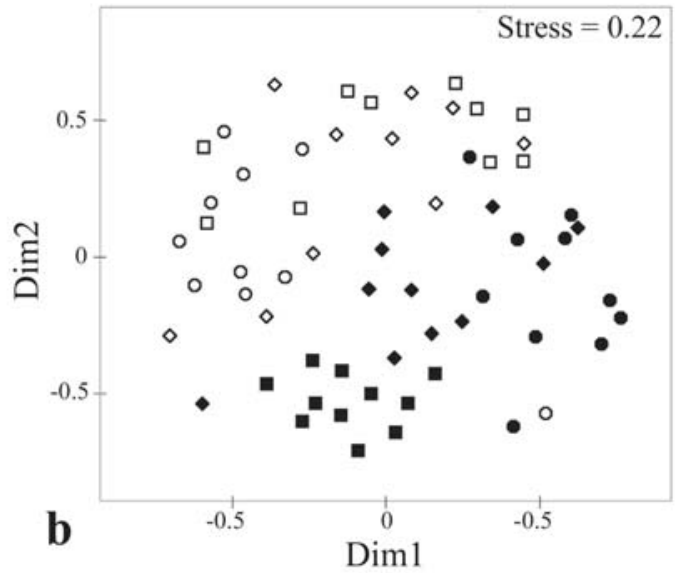

Habitats (gill nets sampling)

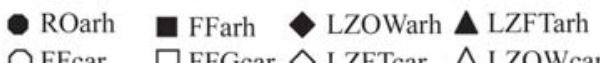

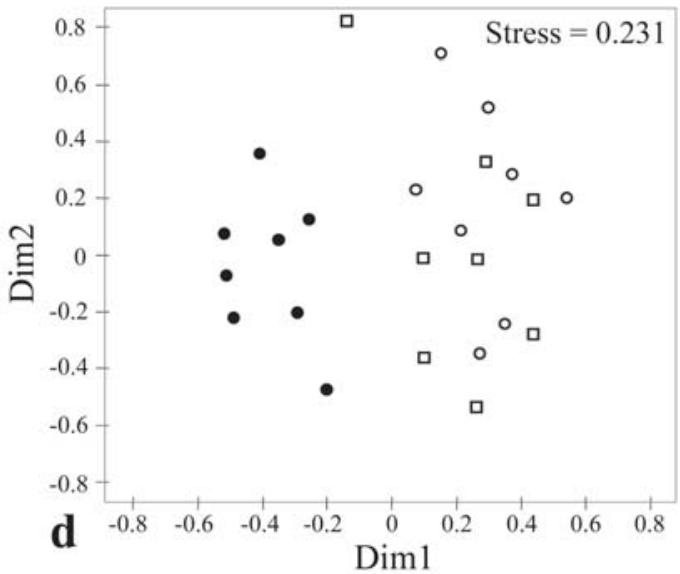

Habitats (seine net sampling)

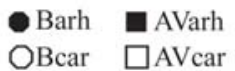

Fig. 6. nMDS analysis during high waters and low waters. a and b = gill nets sampling; $c$ and $d=$ seine net sampling. Each symbol represents one sample, filled symbols belongs to Las Arhuacas (arh) and those of open symbols to Los Cardonales (car). The dissimilarity between the sampling is approximately proportional to the distance, that is to say to greater distance greater dissimilarity. The abbreviations of the habitats are explained in the Fig. 2. 
Table 7. Similarities of percentages (SIMPER) by habitats sampled with gill net (make up $90 \%$ of the similarity for each habitat) during high and low water in both lagoons, indicating too which species contributed more to the dissimilarity between lagoons for each hydrological phase. Av. sim. = Averages similarities.

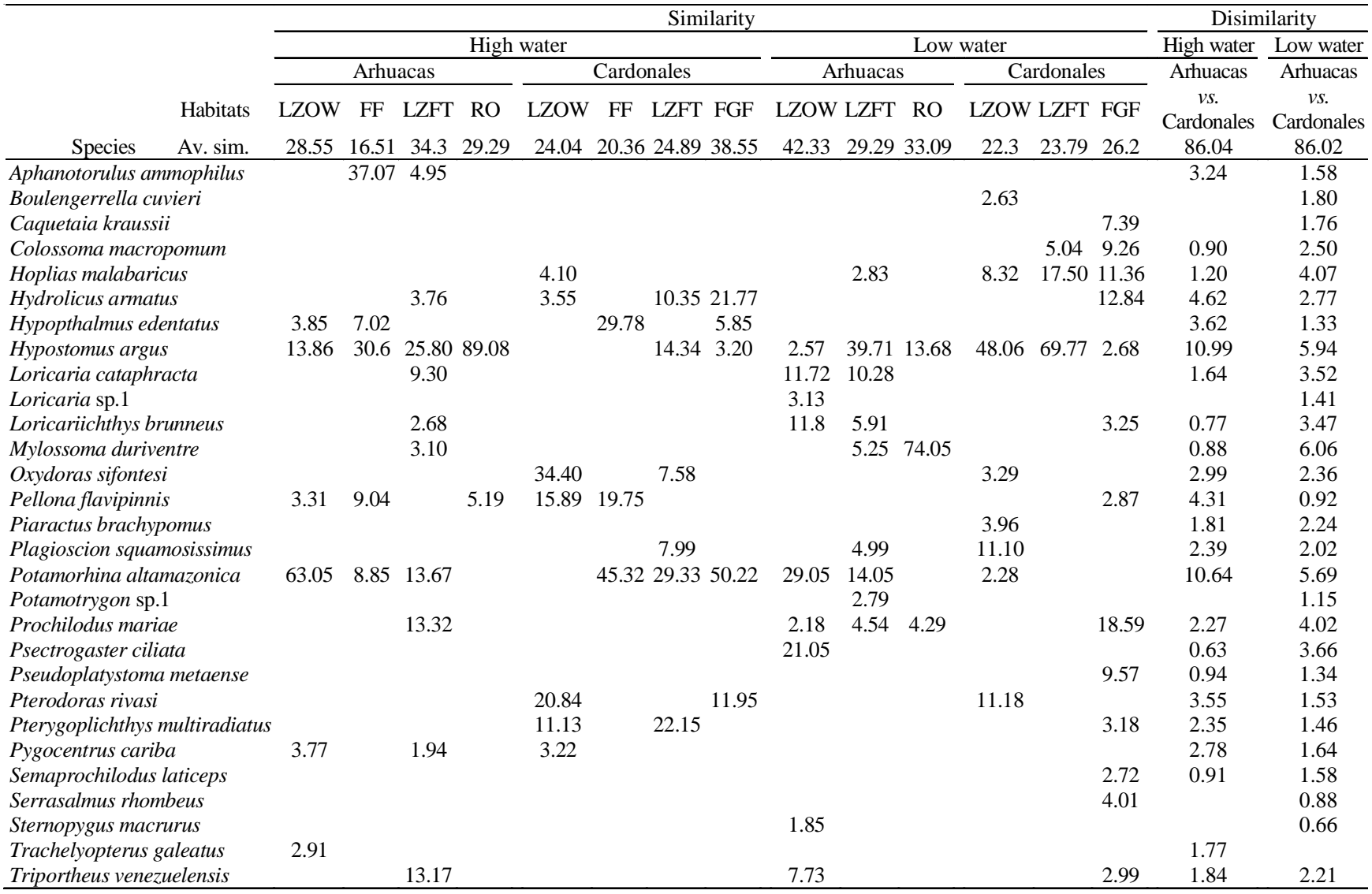

Table 8. Similarities of percentages (SIMPER) by habitats sampled with fine mesh net (make up 90\% of the similarity for each habitat) during high and low water in both lagoons, indicating too which species contributed more to the dissimilarity between lagoons for each hydrological phase. Av. sim. = Averages similarities, B = Beach, AV = Aquatic vegetation.

\begin{tabular}{|c|c|c|c|c|c|c|c|c|c|}
\hline \multirow[b]{5}{*}{ Species } & \multicolumn{7}{|c|}{ Similarity } & \multicolumn{2}{|c|}{ Disimilarity } \\
\hline & \multicolumn{4}{|c|}{ High water } & \multicolumn{3}{|c|}{ Low water } & \multirow{4}{*}{$\begin{array}{c}\text { High water } \\
\text { Arhuacas } \\
\text { vs. } \\
\text { Cardonales } \\
95.05\end{array}$} & \multirow{4}{*}{$\begin{array}{c}\text { Low water } \\
\text { Arhuacas } \\
\text { vs. } \\
\text { Cardonales } \\
86.02\end{array}$} \\
\hline & \multicolumn{2}{|c|}{ Arhuacas } & \multicolumn{2}{|c|}{ Cardonales } & \multirow{2}{*}{$\frac{\text { Arhuacas }}{\text { B }}$} & \multicolumn{2}{|c|}{ Cardonales } & & \\
\hline & B & AV & B & AV & & B & AV & & \\
\hline & 61.1 & 35.84 & 32.35 & 28.76 & 52.1 & 43.56 & 42.82 & & \\
\hline Anchoviella perezi & & & & & 6.06 & 5.73 & 7.63 & 1.94 & 5.48 \\
\hline Aphyocharax alburnus & & 12.42 & 15.39 & & 3.90 & 29.25 & 6.84 & 4.90 & 3.85 \\
\hline Astyanax bimaculatus & & 2.62 & & & & & & 2.11 & \\
\hline Characidium cf. zebra & & 1.37 & & & & & & 0.98 & 0.87 \\
\hline Characidium sp. 1 & & 11.15 & & & & & & 2.91 & \\
\hline Cheirodontops geayi & & & & & 4.58 & & & & 3.37 \\
\hline Curimatella dorsal is & 4.31 & & & & & & & 1.92 & \\
\hline Exodon paradoxus & & 1.36 & 4.02 & & & & & 2.59 & \\
\hline Hemigrammus sp. 1 & & & & & 14.56 & & & 0.74 & 5.85 \\
\hline Hemigrammus sp. 2 aff. mimus & & & & & 6.96 & & & & 4.08 \\
\hline Hemigrammus sp. 3 aff. micropterus & & 3.03 & & & & & & 1.77 & \\
\hline Microphilypnus ternetzi & & 1.34 & & & & & & 1.06 & 0.54 \\
\hline Moenkhau sia sp. 1 "gr. lepidura" & 85.29 & 46.42 & & & 3.93 & & & 22.43 & 2.74 \\
\hline Moenkhausia sp. 2 & & & 47.52 & 42.63 & & 31.84 & 24.59 & 9.25 & 6.89 \\
\hline Moenkhausia sp. 3 & & & 5.41 & 10.13 & 2.98 & 12.92 & 20.54 & 2.97 & 4.33 \\
\hline Odontostilbe pulchra & & 2.85 & & & 19.86 & & & 1.89 & 7.58 \\
\hline Poecilia re ticulata & & 1.52 & & & & & & 1.32 & 0.79 \\
\hline Rachovia maculipinnis & 4.41 & & & & & & & 2.10 & \\
\hline Rhinosardinia amazonica & & & 17.91 & 27.34 & 28.50 & 10.93 & 26.14 & 8.11 & 8.73 \\
\hline Roeboides dientonito & & & & 9.94 & & & 9.95 & 2.50 & 2.30 \\
\hline Triportheus venezuelens is & & 6.27 & & & & & & 3.53 & 0.79 \\
\hline
\end{tabular}


Moenkhausia sp. 2, A. alburnus and E. paradoxus were more commonly collected in beach and, Rhinosardinia amazonica, Moenkhausia sp. 3 and Roeboides dientonito in AV.

During LW for Las Arhuacas, R. amazonica, O. pulchra, Hemigrammus sp. 1, Hemigrammus sp. 2 aff. mimus and Cheirodontops geayi were the species more common in Beach. While, for Los Cardonales, Moenkhausia sp. 2 and A. alburnus were more commonly in Beach and Rhinosardinia amazonica, Moenkhausia sp. 3, Roeboides dientonito and A. perezi, in AV.

SIMPER analysis identified too those species that contributed most to the dissimilarity of the assemblages between lagoons. In the case of samplings with gill net (Table 7) the most important these were, during HW, H. argus, $P$. altamazonica, $P$. flavipinnis, A ammophilus, $H$. armatus, $H$. edentatus, $P$. rivasi, and $O$. sifontesi. The last four species were more commonly collected in Los Cardonales. On the other hand, during LW the most important these were, $M$. duriventre, H. argus, $P$. altamazonica, $P$. mariae, $P$. ciliata, L. cataphracta, L. brunneus, $H$. malabaricus, H. armatus, C. macropomum and $O$. sifontesi. The last five species being more commonly collected in Los Cardonales.

In the case of the habitats $\mathrm{B}$ and $\mathrm{AV}$, the species that contributed most to the dissimilarity during HW, were Moenkhausia sp. 1 "lepidura", Moenkhausia sp. 2, R. amazonica, A. alburnus, T. venezuelensis (young), Characidium sp. 1, Moenkhausia sp. 3, E. paradoxus and $R$. dientonito. In the same way, the last three species were more commonly collected in Los Cardonales. While, during LW, were R. amazonica, O. pulchra, Hemigrammus sp. 1, A. perezi and Moenkhausia sp. 2, being this last specie most abundant in Los Cardonales.

\section{Discussion}

Seasonal-spatial variability in fish abundance, biomass, richness and diversity. Significantly lower fish abundance, biomass and richness were found in Los Cardonales, in spite of the fact that this lagoon had a greater coverage of aquatic vegetation than Las Arhuacas. This could be related to the influence of high anthropogenic intervention in Los Cardonales (González et al., unpubl. data). Such vegetation coverage usually creates important biotopes that provide shelter, oxygen and food, especially for small fish (Delariva et al., 1994; Bennemann et al., 1995). The vegetation also results in greater habitat heterogeneity (Bührnheim, 1999), and consequently in a greater richness and abundance of fishes. However, due to the human impacts too, Los Cardonales lagoon had the lower covering of riparian forest on its shores comparative with Las Arhuacas. Maybe this also demonstrates the highest number of species exclusive to Las Arhuacas that was almost four times greater than in Los Cardonales (55 vs. 17).

Our observations of a high percentage Characiformes species is in keeping with the results of Lasso (1988a, 1988b) from nine floodplain lagoons of the low Orinoco, where
Characiformes represented 35\% of the species, followed by Siluriformes (33\%), Perciformes (18\%) and Gymnotiformes (6\%). Likewise, Rodríguez \& Lewis (1990) in their study of 20 lagoons along the lower Orinoco found the Characiformes to be most common (55\% of the species), followed by the Siluriformes (22\%), Perciformes (8\%) and Gymnotiformes (8\%). The results agree with those from numerous other freshwater ecosystems of the Neotropics where characid and silurid fish predominate (Goulding et al., 1988; Lasso, 1996).

The species abundance was distinctly greater in the AV and $B$ habitats of both lagoons during all the hydrological phases, the fish captured in these habitats were small (generally $<5 \mathrm{~cm} \mathrm{SL}$ ). Such abundance is obviously because the seine net used in the AV and B habitats is not as selective or quick to fill as the gill nets used in the other habitats. A high abundance of $R$. amazonica, which occurred during low water in both of our lagoons, has also been documented by Rodríguez \& Lewis (1994) for other floodplain lagoons of the Orinoco river although their results were for high waters, and they used another fishing system (electric fishing). Perhaps the apparent differences in the seasonal abundances of this specie are due to the different fishing systems used. These authors also reported the high variability in the density of this and another Clupeiformes (A. perezi). Jørgensen (1994) reported $R$. amazonica but with lower values of abundance in the aquatic vegetation (10\%). The two last-mentioned species, in addition to other freshwater clupeids and engraulids, are zooplanktovores of generally pelagic habits and form enormous shoals of fish in both floodplain lagoons and the main channel of the Orinoco River and its tributaries (Pérez, 1984). The availability of zooplankton in both lagoons could not be precisely measured; however during falling water, it was estimated that Los Cardonales had around 300 org/l (González, unpubl. data), which appears relatively high for that hydrological period compared to another lagoon studied by Vásquez \& Sanchez (1984). In addition, the high coverage (approximately $>65 \%$ ) of aquatic vegetation (principally Paspalum repens) along the margins of this lagoon could explain the abundance of zooplankton and, therefore, the greater diversity of clupeids. Jørgensen (1994) also found that clupeids, represented by three species (mainly Anchoviella manamensis), ranked second in abundance (with around $15 \%$ ) in the Castillos lagoon which also has a high coverage of aquatic vegetation.

Regarding biomass (fresh weight), the estimates from both lagoons are lower than that observed in other floodplain lagoons of Venezuela: $571 \mathrm{~kg} / \mathrm{ha}$ (Taphorn \& Lilyestrom, 1984), 280 - $450 \mathrm{~kg} / \mathrm{ha}$ (Lasso, 1996). These were mostly estimated during low waters, when fish are concentrated and hence there is greater biomass. The lower values from Las Arhuacas and Los Cardonales are perhaps due to greater current fishing pressure in association with increased human population density.

The reduced species richness in Los Cardonales may have 
been due to the high levels of human impact, as it was mentioned previously. Los Cardonales was closer to the main channel than Las Arhuacas, a characteristic that usually leads to higher diversity. When this distance is smaller, species richness tends to be greater because of the higher input of nutrients due greater magnitude of the flood pulse (Junk et al., 1989; Lasso, 1996). There were other factors that are also necessary to take into account, like the surface of the lagoon, the vegetation coverage, the height and slope of dike or hill that separates the lagoon from the main channel of the river or stream, the connection time between the main channel and the lagoon, morphology, depth, etc. Nevertheless, the effect of the distance continues to be one of the most important factors, because it is related with the flood pulse (Lasso, 1996; Lasso et al., 1999). Las Arhuacas had the greater species richness in spite of having a higher dike and being farther from the main channel, characteristics which caused it to have a shorter connections with the main channel (from late June to mid October). While Los Cardonales, with its shorter distance (and lower dike), had a longer period of connection with the main channel (from mid May to early November) and yet was less diverse.

Other authors, such as Junk et al. (1989) and Junk \& Wantzen (2004), indicate that the dynamics of the periodic flooding and drying (flood pulse concept) is also one of the main factors regulating the biotic communities of the flood plains. This occurs because of the "aquatic/terrestrial transition zone" (ATTZ) which is responsible for shaping the existence, productivity and interactions of most of the floodplain biota. The biota evolves strategies and adaptations (anatomical, physiological and/or ethological) that help them utilize the ATTZ. Through all these characteristics the organisms are able to avoid physiological stress in the ATTZ, and their adaptations increase the diversity of species in the floodplain especially for mobile organisms like the fish (Junk et al., 1989). These authors also suggest that the flood pulse is a physical disturbance that helps produce and maintain highly diverse habitat structure, something which also enhances diversity. This is consistent with the hypothesis of intermediate disturbance (Connell, 1978). Other authors like Pringle (2003) and Decamps et al. (2004) suggest that the connectivity of the riverside zones with the main channel is a fundamental and essential characteristic for the maintenance of the biodiversity, mainly for those species of fish that need to migrate for reproduction and/or feeding. Junk \& Wantzen (2004) also suggest that the lateral connectivity directly determines the patterns of diversity of many taxonomic groups.

Considering richness at the habitat level, in both lagoons the B and AV habitats had the greatest abundance of fishes. In Las Arhuacas, despite being less covered by aquatic vegetation, such habitat was more species rich ( $>50$ species) than that of Los Cardonales ( $<50$ species). Species richness was greatest during high waters in both lagoons, perhaps because in low waters the levels of human impact increased, especially in Los Cardonales (González et al., unpubl. data).
The ecological diversity (H') present in both lagoons did not exceed one bit and so was lower than that reported by other authors. Lasso (1996) and Lasso et al. (1999) report values for floodplain lagoons of the Apure River basin that oscillated among 1.65 to 3.61 (index of Shannon). According to Goulding et al. (1988), values over three bits indicate high diversity. Machado-Allison (1987) has suggested that there are many reasons for high diversity in the tropics. These include the heterogeneity and availability of niches. According to the theory proposed by Connell (1978), diversity is based upon the variety of niches available and the degree of species specialization. Another idea relates to the surface area of the lagoon as suggested by Castello et al. (1987) who emphasized that increasing the area also increases the diversity of species due to the greater diversity of habitats and resources available. In this study, lagoon size but not habitat heterogeneity could help explain observed diversity. Las Arhuacas, with a greater surface area but lower habitat heterogeneity, had a higher number of species than Los Cardonales which had a higher diversity index, greater habitat heterogeneity but less surface area and fewer species. The difference in diversity indexes between the lagoons was caused by the inequitable distribution of abundance in Las Arhuacas which led to a lower diversity index compared with Los Cardonales. For example, in Las Arhuacas, as has already been mentioned, R. amazonica alone contributed $71 \%$ of the total of number of captured individuals, and that species together with other small characids (Moenkhausia spp., O. pulchra and A. alburnus) and clupeids (A. perezi) represented $90 \%$ of all individuals. In Los Cardonales, the pattern was somewhat similar but $R$. amazonica was lower (it represented $47 \%$ of the individuals). When small species were excluded, Las Aruhuacas had the greater diversity index (1,58 bits vs. 1,5 for Los Cardonales).

Stability and/or variability spatial and seasonal in the fish assemblage. The severe hydrological fluctuation induced by the intervening flood dynamics are one of the most important factors affecting the stability of communities (Medeiros \& Maltchik, 2001). In spite of this, fish assemblages tend to have certain resilience and re-establish themselves in the long term. Perhaps the recovery of fish communities in these floodplains is related to the reproductive strategies of many species, such as the production of recruits to coincide with favorable habitat conditions and the capacity for rapid and extensive dispersal or colonization and this way to achieve the persistence (Poff \& Allan, 1995). Nevertheless, the persistence or existence of fish assemblages in any habitat also depends upon other biotic (competition, depredation, nutritional, morphologic and physiological aspects) and abiotic factors (physicalchemical parameters of the water, food availability and refuge). Also, Medeiros \& Maltchik (2001) and Thomaz et al. (2007) suggested that spatial heterogeneity is important to the maintenance of stability and diversity in communities 
subjected to disturbances.

We found that during high water the abundance per collection for adult fish was more variable and the stability was lower than during the low water phase. That is to say, the fish assemblage fluctuated substantially during high water and was moderately stable during the low water phase in both lagoons, with more stability or less variability across the hydrological phases in Los Cardonales than Las Arhuacas. Rodríguez \& Lewis (1997), in spite of the strong fluctuations induced by the periodic floods, found a similar pattern in the assemblages properties in the two years of studies during the dry season. They also indicated that although the relative abundance including numerical density of small fishes (small tetras) changed significantly within years, such changes were similar from year to year, suggesting a recovery of assemblage properties at the level of individual lagoons soon after annual floods. This might reflect a adjustment or resilience occurring through regulation by deterministic mechanisms. Winemiller (1996) also reported similar results for the persistence of tropical fish assemblages structure between years. He indicated that the species composition in floodplain assemblages can be predicted with a high degree of accuracy each year, especially during the transition period (descending or falling water). Winemiller (1996) also noted that tropical floodplain fish assemblages are structured by a blend of deterministic and stochastic processes operating across a broad range of temporal and spatial scales. The ANOSIM and nMDS ordination analysis corroborate such variability in both hydrological phases, besides identifying the differences in the species assemblages at habitat level between lagoons. These analyses demonstrated that the dissimilarity between fish assemblage structure of the two lagoons was greater during low waters and less during high waters, but the variability or random distribution of fish among different habitats in both lagoons was greater during high waters and less during low waters. This last observation agrees with Arrington (2002), who reported more regular patterns in the relationship between fish communities and habitats during the period of low waters. This author suggested that this regularity is due to the fact that important ecological interactions (availability of food resources, intensity of competition and predation) become greater during this period. Similarly, Lasso (1996) and Lasso et al. (1999) reported that during high water the fish associations appear more random because the natural flooding tends to enhance the intermixture of fish species, while during low water the lagoons become isolated and the fish associations become more unique, especially as the season progresses. Rodríguez \& Lewis (1990) also found high variability in species composition amongst lagoons, but such variability diminished with the spatial proximity of the lagoons. This led them to conclude that small scale (i.e., between two or three near lagoons) differences can be explained according to environmental factors like the morphology of the lagoon and type of vegetation, and that, therefore, the level of inter- association variability related to the scale of the landscape. Layman \& Winemiller (2005) also suggested such a pattern.

In this study, the differences in species composition, at least at a small scale (i.e., between habitats within or across lagoons), could have been mainly influenced by anthropogenic impacts because nowadays many of the floodplains lagoons of the lower Orinoco face threats from human impacts deriving largely from population increase around established settlements. At the same time, we cannot rule out the importance of the environmental factors, including the physical-chemical parameters (González et al., unpubl. data). Human impact around floodplain lagoons was not taken in account by Rodriguez \& Lewis $(1990,1994,1997)$ and yet it must be considered when studying such lagoons in the lower Orinoco at any spatial scale. An example of a particularly alarming human impacts in these lagoons is the indiscriminate fishing, which exercises strong impacts on the fish communities. In Las Arhuacas lagoon such disturbances were very frequent, mainly during low water phases. Perhaps this was also part of the reason for the low abundance of fish predators (piscivorous) which, in turn, probably caused higher abundance of small and medium sized fish and the dominance of some species of little commercial importance (H. argus, Potamorhina altamazonica, Loricaria cataphracta, among others), effects which caused low stability and equitability among the species in Las Arhuacas lagoon. Nevertheless, Tilman et al. (1998) argued that sites containing fish assemblages with high numbers of species and individuals, as happened in this lagoon, may be less susceptible to environmental disturbances. In Los Cardonales, despite the lack of fishing, pollution during low water caused there to be a greater abundance of piscivores (González et al., unpubl. data) and a greater equitability among species resulting in a greater stability of fish communities. Moreover, Rodríguez \& Lewis $(1994,1997)$ argued also that piscivory strongly modifies species relative abundance during the dry season by influencing site selection by prey.

Likewise, there were also differences in species composition between habitats within each lagoon. Rodríguez \& Lewis (1990) also indicated that the patterns observed in the species assemblages associated with the diverse habitats are probably most influenced by the affinities of specific species, especially the variation in the relative abundance of the common species and the presence/absence of rare species. For example, the high abundances of $P$. altamazonica and $H$. argus in the habitats FFG (principally rooted and floating Paspalum repens) and LZFT respectively during high waters, and of $H$. armatus and $H$. malabaricus in FFG and Hypophthalmus spp. in LZOW during low waters, contributed to the significant differences between the respective habitats in Los Cardonales. The reason for the presence of the first two detritivorous species in such habitat could be the high availability of detritus offered by these habitats during high water; these species exploit large deposits of particulate organic matter including microalgae. On the other hand, the presence of $H$. armatus and $H$. malabaricus in habitat FFG 
was related to predation on the great number of fish imprisoned in this habitat during low water, whereas Hypophthalmus spp., which is mainly associated with open water, was probably taking advantage of the high availability zooplankton during this period.

In Las Arhuacas, the main species that contributed to the significant differences in species assemblages between the habitats RO and LZOW together with LZFT during both high and low water were the following: $H$. argus (during high waters) and $M$. duriventre (during low waters) in RO; $P$. altamazonica (during both periods) in LZOW and $P$. mariae (during high waters) and $H$. argus (during low waters) in LZFT. Apparently, all these species, except M. duriventre, are detritivorous, which explains the importance of the detritus in these habitats and therefore in the lagoon especially during high water. The presence of $H$. argus in RO, however, might be due to the lithophilous conduct of this species.

In summary, there seems to have been moderate fish assemblage stability over the hydrological cycle in the studied lagoons, in spite of the human interferences. However, it is necessary to carry out more detailed and long-term studies in these and other lagoons in order to better identify the ecological characteristics that regulate the floodplain fish communities. The similarities or differences amongst the species associations in the mosaic of habitats in floodplains have also been studied by many authors, who have tied these patterns to stochastic or deterministic models associated with hydrological dynamics. For example, in reviewing such patterns, Goulding et al. (1988), Jepsen (1997) and Saint-Paul et al. (2000) emphasized stochastic associations between species and habitats at several spatial scales. Whereas other authors, such as Winemiller (1996), Jepsen (1997), Rodríguez \& Lewis (1997), Cox-Fernández (1999), Hoeinghaus et al. (2003), Petry et al. (2003), and Arrington et al. (2005), have identified non-random (i.e., deterministic) aspects of these patterns relating to the selection of habitats and/or to biological interactions. In the present study, this latter model of association apparently was more common during low waters when there is an increased density of fish and so the biotic interactions are intensified. Stochastic associations, on the other hand, seemed to be more common during high water when species are more dispersed. However, nowadays such associations, besides being regulated by the hydrological dynamics, are also heavily influenced by anthropogenic disturbances that are accelerating in all these floodplain lagoons. These lagoons are important for the maintenance of the fisheries, and the role of these disturbances, therefore, has to be better understood.

\section{Acknowledgements}

Marcela Villar, Giussepe Palumbo, Angela Torres, Mariana Rodriguez, Cristian Duerto, Jonathan and Ramcis assisted with field collections and in the laboratory. Sara Julia, Oly Angulo and Jesus Pérez provided logistical support on occasion. Militza Rodríguez helped me with the maps of the lagoons. Jorge Medina provided logistical support during the field collections. We thank Conrad Vispo especially for the revisions and important suggestions on the manuscript. Luis Pérez contributed information on lagoons of the lower Orinoco. This paper is a part of a dissertation submitted to the Universidad Nacional Experimental de Guayana (UNEG) as a partial requirement for Master Degree in Environmental Sciences mention Applied Ecology. This project formed also part of the Project: Corredor del Orinoco, Phase I.

\section{Literature Cited}

Arrington, D. A. 2002. Evaluation of the relationship between habitat structure, community structure, and community assembly in a Neotropical blackwater river. Unpublished Ph.D. Dissertation, Texas, A\&M University, College Station, 122p.

Arrington, D. A., K. O. Winemiller \& C. A. Layman. 2005. Community assembly at the patch scale in a species rich tropical river. Oecologia, 144(1): 157-167.

Bennemann, S. T., A. T. S. Souza \& G. R. A. Rocha. 1995. Composição ictiofaunística em 5 localidades da bacia do Rio Tibagi, PR - Brasil. Interciencia, 20(1): 7-13.

Bührnheim, C. M. 1999. Habitat abundance patterns of fish communities in three Amazon rainforest streams. Chapter 5, Pp. 63-74. In: Val, A. L. \& V. M. F. Almeida-Val (Eds.). Biology of Tropical Fishes. Manaus, Instituto Nacional de Pesquisas Amazônicas - INPA.

Castello, V., M. Corvillo \& J. E. García. 1987. Relación especiesárea de una comunidad de peces Neotropicales. Miscelánea Zoológica, 11: 243-247.

Clarke, K. R. \& W. M. Warwick. 1994. Similarity-based testing for community pattern: the 2-way layout with no replication. Marine Biology, 118: 167-176.

Clarke, K. R. \& R. M. Warwick. 2001. Change in marine communities: an approach to statistical analysis and interpretation. Plymouth, PRIMER-E Ltda, 86p.

Colonnello, G. 1990. Elementos fisiográficos y ecológicos de la cuenca del río Orinoco y sus rebalses. Interciencia, 15(6): 476-485.

Connell, J. H. 1978. Diversity in Tropical Rain Forests and Coral Reef. Washington, Science, 199p.

Cox-Fernández, C. 1999. Detrended canonical correspondence analysis (DCCA) of electric fish assemblages in the Amazon. Pp. 21-39. In: Val, A. L. \& V. M. F. Almeida-Val (Eds.). Biology of tropical fishes. Manaus, Instituto Nacional de Pesquisas Amazônicas - INPA.

Decamps, H., G. Pinay, R. J. Naiman, G. E. Petts, M. E. McClain, A. Hillbricht -Ikowska, T. A. Hanley, R. M. Holmes, J. Quinn, J. Gibert, A. M. Planty-Tabacchi, F. Schiemer, E. Tabacchi \& M. Zalewski. 2004. Riparian zones: where biogeochemistry meets biodiversity in management practice. Polish Journal of Ecology, 52(1): 3-18.

Delariva, R. L., A. A. Agostinho, K. Nakatani \& G. Baumgartner. 1994. Ichthyofauna associated to aquatic macrophytes in the upper Parana River Floodplain. Revista UNIMAR, 16(Suppl. 3): 41-60.

Ewel, J. J., A. Madriz \& J. A. Tosi. 1976. Zonas de Vida de Venezuela. Caracas, Editorial Sucre, 265p.

Freeman, M. C., M. K. Crawford, J. C. Barret, D. E. Facey, M. G. Flood, J. Hill, D. J. Stouder \& G. D. Grossman. 1988. Fish assemblages stability in a Southern Appalachian Stream. Canadian Journal of Fisheries and Aquatic Sciences, 45: 1949-1958. 
Goulding, M., M. Leal-Carvalho \& E. G. Ferreira. 1988. Rio Negro: Rich life in poor water. The Hague, SPB Academic Publishing, 200p.

Grossman, G. D., J. F. Dowd \& M. Crawford. 1990. Assemblages stability in stream fishes: A review. Environmental Management, 14(5): 661-671.

Hamilton, S. \& W. Lewis Jr. 1990.Basin morphology in relation to chemical and ecological characteristics of lagoons on the Orinoco River Floodplain, Venezuela. Archiv für Hydrobiologie, 119(4): 393-425.

Hoeinghaus, D. J., C. A. Layman, D. A. Arrington \& K. O. Winemiller. 2003. Spatio-temporal variation in fish assemblage structure in tropical floodplain creeks. Environmental Biology of Fishes, 67: 379-387.

Jepsen, D. B. 1997. Fish species diversity in sand bank habitats of a Neotropical river. Environmental Biology of Fishes, 49(4): 449-460.

Jørgensen, J. 1994. Fish communities associated to macrophytes in floodplain lagoons, Orinoco drainage, Venezuela. Unpublished MSc. Dissertation, Denmark, The Zoological Museum of Copenhagen, 79p.

Jørgensen, J., C. A. Lasso \& L. Blanco-Belmonte. 2000. Fish biomass and density in macrophyte habitats in floodplain lagoons of the Orinoco Basin, Venezuela. Memoria de la Fundación La Salle de Ciencias Naturales, (153): 35-49.

Junk, W., P. Bayley \& R. Sparks. 1989. The flood pulse concept in river-floodplain system. In: Proceedings of the International Large River Symposium. Dodge, D. P. (Ed.). Canadian Special Publications in Fish and Aquatic Science, 106: 110-127.

Junk, W. J. \& K. M. Wantzen. 2004. The flood pulse concept: new aspects, approaches and applications - an update. Pp. 117140. In: Welcomme, R. L. \& T. Petr (Eds.). Proceedings of the Second International Symposium on the Management of Large Rivers for Fisheries, Volume II. Food and agriculture organization of the united nations \& the mekong river commission, Phnom Penh, Kingdom of Cambodia.

Langeani, F., L. Casatti, H. S. Gameiro, A. Bellucco do Carmo \& D. de C. Rossa-Feres. 2005. Riffle and pool fish communities in a large stream of southeastern Brazil. Neotropical Ichthyology, 3(2): 305-311.

Lasso, C. 1988a. Inventario de la ictiofauna de nueve lagunas de inundación del Bajo Orinoco, Venezuela. Parte I: BatoideiClupeomorpha-Ostariophysi (Characiformes). Memoria de la Fundación La Salle de Ciencias Naturales, (130): 121-141.

Lasso, C. 1988b. Inventario de la ictiofauna de nueve lagunas de inundación del Bajo Orinoco, Venezuela. Parte II: Siluriformes-Gymnotiformes-Acanthopterygii. Memoria de la Fundación La Salle de Ciencias Naturales, 48(Suppl. 2): 355-382.

Lasso, C. 1996. Composición y aspectos bioecológicos de las comunidades de peces del Hato el Frío y Caño Guaritico, Llanos de Apure, Venezuela. Unpublished Ph.D. Dissertation, Sevilla, Universidad de Sevilla, Facultad de Biología, Departamento de Biología Vegetal y Ecología, 688p.

Lasso, C. A., A. Rial \& O. M. Lasso-Alcalá. 1999. Composición y Variabilidad espacio-temporal de las comunidades de peces en ambientes inundables de los llanos de Venezuela. Acta Biológica Venezuelica, 19(2): 1-28.

Layman, C. A. \& K. O. Winemiller. 2005. Patterns of habitat segregation among large fishes in a Venezuelan floodplain river. Neotropical Ichthyology, 3(1): 103-109.
Lewis, W. M. Jr., J. F. Saunders III, S. A. Levines \& F. Weibezahn. 1986. Organic carbon in the Caura River, Venezuela. Limnology and Oceanography, 31: 653-656.

Machado-Allison, A. 1987. Los peces de los llanos de Venezuela: un ensayo sobre su historia natural. Consejo de Desarrollo Científico y Humanístico. Caracas, Universidad Central de Venezuela, 144p.

Machado-Allison, A. 1994. Factors affecting fish communities in the flooded plains of Venezuela. Acta Biológica Venezuelica, 15(2): 59-75.

Meade, R. H., C. F. Nordin, D. Pérez-Hernández, A. Mejia \& J. M. Pérez-Godoy. 1983. Sediment and water discharge in Orinoco River, Venezuela and Colombia. Pp. 1134-1144. In: Proceedings of the Second International Symposium on River Sedimentation, Water Resources and Electric Power Press. Beijing, China.

Medeiros, E. S. F. \& L. Maltchik. 2001. Diversity and stability of fishes (Teleostei) in a temporary river of the Brazilian Semiarid Region. Iheringia, Série Zoologia, 90: 157-166.

Meffe, G. K. \& W. L. Minckley. 1987. Persistence and stability of fish and invertebrate assemblages in a repeatedly disturbed Sonoran desert stream. American Midland Naturalist, 117(1): 177-191.

Pérez, L. 1984. Ecología y factibilidad de cultivo de los Engraulidae dulceacuícolas del Río Orinoco. Memoria de la Asociación Latinoamericana de Acuacultura, 5(3): 533-541.

Petry, P., P. B. Bayley \& D. F. Markle. 2003. Relationships between fish assemblages, macrophytes and environmental gradients in the Amazon River floodplain. Journal Fish Biology, 63: 547-579

Poff, N. L. \& J. D. Allan. 1995. Functional organization of stream fish assemblages in relation to hydrologic variability. Ecology, 76: 606-627.

Pringle, C. M. 2003. What is hydrologic connectivity and why is it ecologically important? Hydrological Processes, 17(13): 26852689.

Rodríguez, M. A. \& W. M. Lewis Jr. 1990. Diversity and species composition of fish communities of Orinoco floodplain lagoons. National Geographic Research, 6: 319-328.

Rodríguez, M. A. \& W. M. Lewis Jr. 1994. Regulation and stability in fish assemblages of Neotropical floodplain lagoons. Oecologia, 99: 166-180.

Rodríguez, M. A. \& W. M. Lewis Jr. 1997. Structure of fish assemblages along environmental gradients in floodplain lagoons of the Orinoco river. Ecological Monographs, 67: 109-128.

Saint-Paul, U., J. Zuanon, M. A. V. Correa, M. Garcia, N. N. Fabre, U. Berger \& W. J. Junk. 2000. Fish communities in central Amazonian white- and blackwater floodplains. Environmental Biology of Fishes, 57: 235-250.

Shannon, G. \& W. Wiener. 1949. The Mathematical Theory of Communication. Urbana, University Illinois Press, 177p.

Sokal, R. R. \& F. J. Rohlf. 1995. Biometry. New York, W. H. Freeman and Company, 859p.

Taphorn, D. \& C. Lilyestrom. 1984. Los peces del Módulo "Fernando Corrales". Resultados ictiológicos del proyecto de investigación del CONICIT-PIMA N ${ }^{\circ}$ 18. Revista UNELLEZ Ciencia y Tecnologia, 2: 55-85.

Thomaz, S. M., L. M. Bini \& R. L. Bozelli. 2007. Floods increase similarity among aquatic habitats in river-floodplain systems. Hydrobiologia, 579: 1-13.

Tilman, D., C. L. Lehman \& C. E. Bristow. 1998. Diversity-stability relationships: statistical inevitability or ecological consequence? The American Naturalist, 151: 277-282. 
Vásquez, E. \& L. Sánchez. 1984. Variación estacional del plancton en dos sectores del río Orinoco y una laguna de inundación adyacente. Memoria de la Fundación La Salle de Ciencias Naturales, 121(44): 11-32.

Winemiller, K. O. 1996. Dynamic diversity in fish assemblages of tropical rivers. Pp. 99-132. In: Cody, M. L. \& J. A. Smallwood (Eds.). Long-term Studies of Vertebrate Communities. San diego, Academic Press Inc., 597p.

Zinck. A. 1977. Ríos de Venezuela. Caracas, Cuadernos Lagoven, 63p.

Accepted July 14, 2009

Published December 18, 2009 